\title{
Foreign Trades from Tax Havens on the KOSDAQ*
}

\author{
Cheol-Won Yang ${ }^{* *}$, Associate Professor, Dankook University
}

\begin{abstract}
$\langle$ Abstract $\rangle$
This study uses Korean KOSDAQ market data to verify whether foreign trades from tax havens have significant stock return predictability. To do this, we first examine the amount of foreign transactions by country and then define tax havens as the five largest havens as designated by the OECD (the Cayman Islands, Bermuda, US Virgin Islands, British Virgin Islands, and the Bahamas). They account for $14.22 \%$ of the total foreign transactions on the KOSDAQ. The results on the return predictability of tax haven trades are as follows. First, when constructing the portfolio, the hedge portfolio, which buys the portfolio with the highest net purchase and sells the one with the lowest, has a significant return of $0.61 \%$ per day (13.42\% per month). The statistical significance of hedge portfolio returns remains even if the holding period is increased by five days. In the regression analysis, the tax haven net purchases significantly predict the stock return of the next day. In particular, the magnitude of the stock return predictability of the KOSDAQ market is much stronger than that of the KOSPI market reported in previous research (0.28\% per day). This is further evidence that tax haven foreigners in the Korean stock market are informed traders.
\end{abstract}

Keywords: Tax Haven; Foreign Trade; KOSDAQ Market; Return Predictability; Portfolio JEL Classification: G11, G14, G18

* I am grateful to Donglim Shin and participants of the Korean Securities Association annual meeting in February 2019 for their helpful comments. This research was supported by New Scholars Grant Program from the Korean Securities Association and Mirae Asset in 2018.

** Corresponding Author. Address: School of Business Administration, Dankook University, 152 Jukjeon-ro Suji-gu Yongin-si Gyeonggi-do, Korea 16890; E-mail: yang@dankook.ac.kr; Tel: +82-31-8005-3437; Fax: +82-31-8021-7208.

Received: March 26, 2019; Revised: November 7, 2019 \& December 5, 2019; Accepted: December 27, 2019 


\title{
코스닥 시장에서 조세피난처 외국인의 거래"
}

\author{
양 철 원 (단국대학교 부교수)**
}

\begin{abstract}
본 논문은 한국 코스닥 시장에서 활동하는 조세피난처 외국인들의 거래 현황과 거래의 주가예측력에 대해 살펴보았다. 조세피난처로는 $\mathrm{OECD}$ 리스트 37개국 중 코스닥 시장에서 거래규모가 가장 큰 케이만제도, 버뮤다, 미국령 버진아일랜드, 영국령 버진아일랜드, 바하마 5 개국을 정의하였다. 2006년 1 월부터 2009년 8월까지 표본기간 동안 이들의 거래금액은 코스닥 시장 전체 외국인 거래의 $14.22 \%$ 를 차지하였다. 또한 조세피난처 거래는 유의미한 주가예측력을 가지고 있었다. 조세피난처 순매수금액 비율이 가장 높은 주식들을 매입하고 가장 낮은 주식들을 공매도하는 헤지포트폴리오는 일평균 $0.61 \%$ (월 $13.42 \%)$ 의 유의미한 수익률을 가졌다. 헤지포트폴리오 수익률의 통계적 유의성은 보유기간을 5 일까지 증가시킨 경우에도 유지되었다. 회귀분석에서도 조세피난처 순매수금액비율이 다음 날 주식 수익률을 유의하게 예측하였다. 특히 본 연구에서 보고한 코스닥 시장에서의 주가예측력의 크기는 유가증권시장을 대상으로 한 기존 연구결과(일평균 $0.28 \%$ )보다 훨씬 강하였다. 이는 한국 주식시장에서 활동하고 있는 조세피난처 외국인들이 정보거래자임을 지지하는 또 하나의 증거이다.
\end{abstract}

핵심 단어 : 조세피난처, 외국인 거래, 코스닥 시장, 주가예측력, 포트폴리오

JEL 분류기호: G11, G14, G18

* 본 논문에 대해 유익한 조언을 해주신 신동림 박사님과 2019년 2월 한국증권학회 정기학술대회 참가자들께 감사드립니다. 본 연구는 2018년도 한국증권학회-미래에셋자산운용 신진학자 연구지원 사업의 지원을 받아 수행되었습니다.

** 연락담당 저자. 주소: 경기도 용인시 수지구 죽전로 152 단국대학교 경영학부 상경관 511호, 16890; E-mail: yang@dankook.ac.kr; Tel: 031-8005-3437; Fax: 031-8021-7208. 


\section{1. 서론}

조세피난처는 아직 미지의 영역이다. 조세피난처는 그 이름과 같이 '조세회피'를 목적으로 사용되는 지역을 의미하기 때문에 세금과 관련된 연구들이 주를 이룬다(Dyreng et al., 2013; Hanlon et al., 2015). 하지만 조세피난처는 세금과 관련된 요소 외에도 개인정보에 대한 철저한 보호가 핵심적 특징이다. 조세피난처를 세금보다도 자신의 정보를 숨기기 위한 목적으로 이용하는 사람들도 많다. 이러한 익명성은 극단적인 정보의 불투명을 의미하며, 증권시장의 중요 주제를 다룰 수 있는 좋은 실험장을 제공해 준다.

정보비대칭 상황 하에서 정보거래자(informed trader)의 거래를 통해 그들의 사적정보(private information)가 가격에 반영된다는 이론은 증권가격의 형성과정을 설명하는 대표적인 패러다임 이다.1) 이런 패러다임 속에서 여러 질문들이 제기될 수 있다. 첫째, '누가 사적정보를 가지고 있는 정보거래자인가?'이다. 이에 대해서는 다양한 실증분석 연구들이 존재한다. 본 연구의 관심대상은 조세피난처 외국인 투자자들이다. Yang(2015b)은 한국 유가증권시장(KOSPI market)에 들어오는 조세피난처 외국인 거래가 유의한 주가예측력을 가지고 있음을 발견하였으며 이에 근거하여 조세피난처 외국인 투자자들이 정보거래자임을 주장하였다. 하지만 코스닥 시장 (KOSDAQ market)에 대한 연구는 아직 이루어지지 않았다.

또 다른 질문은 사적정보를 가진 정보거래자들의 거래행태에 대한 것이다. 즉, '정보거래자는 자신의 사적정보로 최대 이익을 획득하기 위해 어떤 거래전략을 사용할 것인가?’이다. 우선 정보거래자들은 불투명한 시장구조(market design)를 더 선호하는 것으로 알려져 있다. Grammig et al.(2001)은 독일에서 익명성을 보장해주는 시장과 보장해주지 않는 시장이 동시에 존재하는 상황에서 정보거래자들이 익명성을 보장해주는 시장을 통해 거래함을 보여주었다. 기업특성 측면에서도 기업규모가 작고 애널리스트 커버리지가 작은 종목들에서 정보거래가 더 활발하게 발생한다고 알려져 있다(Easley et al., 2002; Brennan and Subrahmanyam, 1995). 더 나아가 정보거래자들은 적극적으로 자신의 정체를 숨기는 거래전략을 사용하기도 한다. Barclay and Werner(1993)는 정보거래자들이 주문을 낼 때 대규모의 주문을 사용하지 않고 자신을 숨기기 위해 중규모의 주문을 이용함을 주장하였으며, 이를 '은닉거래가설(stealth trading hypothesis)' 이라 명명하였다. Chakravarty(2001)는 미국에서 기관투자자들이 은닉거래가설과 일치한 거래행태를 보이며 정보거래자임을 주장하였으며, Anand and Chakravarty(2007)는 미국 옵션시장에서도 은닉거래가설이 성립함을 보여주었다. Choe et al.(2003)도 한국 주식시장 에서 은닉거래가설과 일치하는 결과를 발견하였다.

1) 이 패러다임은 거래자들을 정보거래자(informed trader)와 비정보거래자(uninformed trader)로 구분하는 정보비대칭 상황을 설정한다. 정보거래자는 아직 가격에 반영되지 않은 사적정보를 가지고 있으며 이를 사용하여 자신의 이익을 극대화하고자 거래하며, 비정보거래자는 정보 외에 다른 동기에 의해서 거래에 참여하게 된다. 이들의 거래를 통해서 사적정보가 가격에 반영되는 과정을 분석할 수 있다. 이에 대한 이론 연구로는 Grossman and Stiglitz(1980), Kyle(1985), Glosten and Milgrom (1985), Easley and O’hara(1987, 2004), Admati and Pfleiderer(1989) 등이 있다. 
본 논문은 한국 코스닥 시장에서 조세피난처 외국인 거래의 주가예측력에 대해 살펴봄을 통해 위에서 언급한 두 문헌에 대해 다음과 같이 공헌하고자 한다. 첫째, 조세피난처로부터 들어오는 외국인들이 정보거래자라는 더 추가적인 증거를 제공하고자 한다. 조세피난처 투자자들의 정보력에 대한 기존 연구는 한국 유가증권시장에 대한 Yang(2015b)의 연구 외에는 찾기 어렵다. $\operatorname{Yang}(2015 \mathrm{~b})$ 의 주장처럼 한국 유가증권시장에서 조세피난처 외국인들이 정보거래 자라면, 동일한 논리에 의해서 코스닥 시장의 조세피난처 외국인들도 정보거래자일 것으로 유추할 수 있다. 이것이 사실이라면 코스닥 시장의 조세피난처 거래에 대해 유의한 주가예측력을 발견할 수 있어야 할 것이다. 이에 따라 본 연구에서는 다음 가설을 검증하고자 한다.

가설 1: 한국 코스닥 시장에 들어오는 조세피난처 외국인들은 정보거래자(informed trader) 이다.

둘째는 코스닥 시장과 유가증권 간의 비교를 통해 조세피난처 외국인의 거래행태를 분석 하고자 한다. 정보거래자들은 사적정보를 통한 이익을 극대화하기 위하여 불투명한 시장을 선호한다는 것으로 알려져 있다. 한국에서 코스닥 시장은 유가증권시장에 비해서 기업규모도 작고 애널리스트 커버리지도 작은, 즉 전반적으로 관심을 덜 받는 시장이다. 이런 시장 특성을 고려할 때, 조세피난처 외국인들이 정보거래자라면 그 주가예측력이 유가증권시장보다 코스닥 시장에서 더 강하게 나타나야 할 것이다. 따라서 본 연구에서는 다음의 가설을 설정하고 검증하고자 한다.

가설 2: 정보거래자들이 불투명한 시장을 더 선호한다면, 코스닥 시장에서 조세피난처 외국인 거래의 주가예측력은 유가증권시장보다 더 클 것이다.

본 논문은 조세피난처 외국인에 대한 기존 연구가 유가증권시장에 한정되었던 것에서 더 나아가 코스닥 시장을 대상으로 살펴보고는 데 그 의의가 있다. 이를 통해 한국 주식시장에 들어오는 조세피난처 외국인들을 더 명확히 이해할 수 있다. <그림 $1>$ 은 두 번째 가설을 기존 문헌과 비교하여 보여주고 있다. 기존의 $\mathrm{Yang}(2015 \mathrm{~b})$ 의 연구는 유가증권시장에서 조세피난처 외국인 순매수금액비율의 헤지포트폴리오가 일평균 $0.28 \%$ 의 수익률을 제공함을 보고하고 있다. 주가예측력의 원인으로는 헤지펀드 같은 '진짜 외국인'의 정보력과 외국인으로 위장한 한국인이 보유한 사적정보 두 가지 가능성을 언급하고 있다. 후자를 일명 '검은머리 외국인'이라 부르기도 한다.

일반적으로 진짜 외국인들은 정보비대칭이 작은, 기업규모가 큰 주식을 선호하는 것으로 알려져 있다. 이런 점에서 보면, <그림 $1>$ 에서와 같이 코스닥 시장에서 위장한 한국인의 존재가 상대적으로 더 큰 비중을 가질 것이다. 따라서 코스닥 시장에서 헤지포트폴리오의 수익률이 유가증권시장에 비해 크다면 위장한 한국인의 강한 정보력에 대한 가설을 더 지지하는 결론으로 이해할 수 있다. 반대로 코스닥의 수익률이 유가증권시장보다 작다면 위장한 한국인의 정보력이 약하거나 의미 없는 것으로 결론내릴 수 있다. 


\section{〈그림 1〉가설 설정}

본 그림은 두 번째 가설의 의미를 기존 문헌과 비교하여 보여주고 있다. 기존 문헌은 유가증권시장에서 조세피난처 외국인 순매수금액비율 헤지포트폴리오가 일평균 $0.28 \%$ 의 수익률을 제공함을 제시하고 있으며, 주가예측력의 원인으로 헤지펀드 같은 진짜 외국인의 정보력과 위장한 한국인이 보유한 사적정보 두 가지 가능성을 언급하고 있다. 유가증권시장에서 진짜 외국인과 위장한 한국인의 비중에 비해서 코스닥 시장에서는 위장한 한국인의 존재가 상대적으로 더 큰 영향을 가질 것이다. 따라서 코스닥 시장의 헤지포트폴리오 수익률이 유가증권시장에 비해 크다면 위장한 한국인의 강한 정보력에 대한 가설을 더 지지하는 결론으로 이해할 수 있다. 반대로 코스닥 시장의 수익률이 유가증권시장에 비해 작다면 위장한 한국인의 정보력은 약하거나 의미 없는 것으로 결론내릴 수 있다.

\section{유가증권 시장}

- 헤지포트폴리오 수익률 (0.28\% per day)

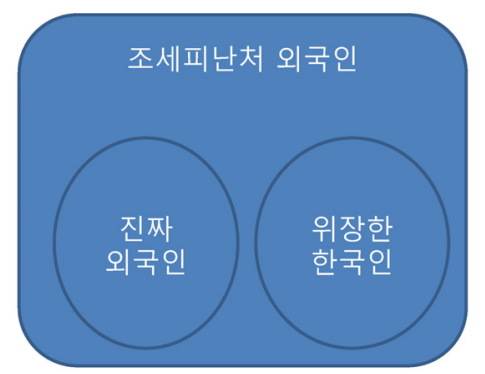

\section{코스닥 시장}

- 헤지포트폴리오 수익률 ( ? per day)

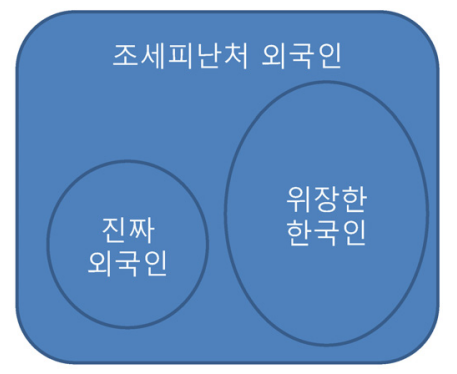

본 연구의 절차와 방법론은 $\operatorname{Yang}(2015 \mathrm{~b})$ 과 동일하다. 재무에서 일반적으로 사용하는 포트 폴리오 및 회귀분석의 방법을 사용하여 조세피난처 외국인 순매수거래금액비율의 주가예측력을 검증하였다. 이는 $\mathrm{Yang}(2015 \mathrm{~b})$ 의 유가증권시장에서의 결과와 비교하기 위해 반드시 필요한 절차이기도 하다. 연구는 먼저 한국 코스닥 시장을 대상으로 조세피난처로부터의 외국인 거래의 전반적인 현황을 살펴보며, 이후에 주가예측력을 검증하는 순으로 진행하였다.

본 연구의 주요 결과는 다음과 같다. 첫째, 코스닥 시장에서 조세피난처 외국인 투자자들의 거래규모는 국가 경제규모에 비해 이해하기 어려울 정도로 컸다. 2006년 1월부터 2009년 8월까지 코스닥 시장에 상장된 보통주들의 외국인 거래 내역을 국가별로 합계한 후, $\mathrm{OECD}$ 가 지정한 조세피난처 국가에 해당하는 케이만제도, 버뮤다, 미국령 버진아일랜드, 영국령 버진아일랜드, 바하마 5개국을 조세피난처로 정의하였다. 이들 5개국은 $\operatorname{Yang}(2015 \mathrm{a}, 2015 \mathrm{~b})$ 에서 보고한 유가증권시장에서의 조세피난처 상위 5 개국의 명단과 동일하다. 이들 조세피난처의 거래는 전체 외국인 거래금액의 $14.22 \%$ 를 차지하였으며, 이 수치는 미국의 $14.77 \%$ 와도 큰 차이가 나지 않는다. 조세피난처 중에서는 케이만제도가 $11.54 \%$ 로 가장 큰 비중을 차지하였다.

둘째, 조세피난처 외국인 순매수금액비율에 따라 포트폴리오를 구성하여 주가예측력을 검증하였다. 분석결과, 순매수금액비율이 높은 포트폴리오가 낮은 포트폴리오보다 더 높은 수익률을 가졌다. 순매수금액비율이 가장 낮은 주식들을 공매도하고 가장 높은 주식들을 매수하는 헤지포트폴리오의 수익률이 일평균 $0.61 \%$ 로 통계적으로 유의미하였다. CAPM을 사용한 위험조정 수익률도 동일한 결과를 보여주었다. $\mathrm{Yang}(2015 \mathrm{~b})$ 에서 보고한 유가증권시장에서의 
Foreign Trades from Tax Havens on the KOSDAQ

헤지포트폴리오 일평균 수익률이 $0.28 \%$ 임을 볼 때, 수익률 크기가 2 배가 넘는다. 이는 조세피난처 거래의 주가예측력이 유가증권시장에서보다 코스닥 시장에서 훨씬 강함을 보여준다.

셋째, 기업특성별로 주식들을 구분하여 조세피난처 거래의 주가예측력을 살펴보았다. 실증분석 결과, 기업규모가 작고, 외국인 지분율이 낮은 주식들에서 주가예측력이 더 강하게 발견되었다. 마지막으로 회귀분석을 통한 검증에서도 유의한 주가예측력을 확인할 수 있었다. 주식 수익률을 종속변수로, 조세피난처 외국인의 순매수금액비율을 독립변수로 사용한 회귀분석에서 회귀 계수가 유의미하였다. 기업규모나 유동성 등을 통제변수로 추가하였을 때도 결과는 동일하였다. 이는 조세피난처 외국인들이 주가예측 능력을 가지고 있음을 일관되게 지지하는 결과이다.

한국 주식시장에서 조세피난처 외국인에 대한 연구는 다음과 같은 두 가지의 흐름으로 요약할 수 있다. 첫 번째 흐름은 조세피난처 외국인 거래가 주식시장에 미치는 영향력에 대한 연구이다. Kim and Wei(2002)는 1996년 1999년 기간을 대상으로 하여 당시 한국 주식을 보유하고 있던 바하마, 바레인, 버뮤다, 케이만제도 등의 역외펀드(offshore fund) 133 개의 거래행태와 주식시장에 대한 영향력을 연구하였다. 역외펀드는 역내펀드(onshore fund)보다 더 자주 거래 하지만, 금융위기 기간 동안의 무리행동(herding) 수준은 오히려 더 작았으며 추세추종매매 (positive feedback trading) 행태도 발견할 수 없었다. 이를 근거로 Kim and Wei(2002)는 조세피난처 역외펀드가 금융위기 기간 한국 주식시장을 붕괴시키는 역할을 하지는 않았음을 결론내리고 있다. Yang(2015a)는 2006년 1월부터 2008년 6월 동안 한국 유가증권시장에 들어오는 조세피난처 외국인 투자자들의 전체적인 현황과 그들의 영향력에 대해 연구하였다. 조세피난처 외국인들은 추세추종매매 행태를 보이며, 그들의 매매는 유의미한 가격충격을 지니며 변동성을 증가시켰다. 이를 근거로 $\mathrm{Yang}$ (2015a)은 조세피난처가 더욱 투명하게 개선되어야 함을 주장하며, $\mathrm{OECD}$ 와 $\mathrm{G} 20$ 이 진행하고 있는 조세피난처 개선조치들을 지지하였다. Jung and $\mathrm{Kim},(2017)$ 는 조세피난처 투자자의 지분 보유가 투자기업의 기업가치, 기업지배구조, 배당 및 투자, 효율성, 기업고유위험(idiosyncratic risk)과 유의미한 관계를 있음을 발견하지 못하였지만, 유동성을 악화시키고 변동성을 증가시키는 부분에서는 부정적인 영향이 있음을 발견하였다.

두 번째 흐름은 정보 측면에서 조세피난처 외국인에 대한 연구이다. Yang(2015b)은 2005년 8월부터 2009년 8월까지 한국 유가증권시장 자료를 사용하여 조세피난처 외국인 순매수거래금액 비율이 주가예측력이 있으며 조세피난처 외국인들이 정보거래자임을 주장하였다.

본 연구는 후자와 같이 정보 측면에서 코스닥 시장의 조세피난처 외국인들을 분석하여 이들이 정보거래자임을 지지하는 결과를 보여주고 있다. 분석 결과, 코스닥 시장에서 발견된 조세피난처 순매수금액비율에 의한 헤지포트폴리오 수익률은 Yang(2015b)에서 보고된 유가증권시장의 수익률의 2 배를 넘어선다. 이는 정보거래자들이 더 큰 이익을 얻을 수 있는 불투명한 시장을 통하여 거래하고자 하는 유인이 존재함을 의미하며 기존 문헌의 결과와도 일치한다. 한국 코스닥 시장은 이미 유가증권시장에 비해서 내부자 거래, 주가조작 등의 불공정 거래가 훨씬 더 심한 시장으로 알려져 있다. 이는 조세피난처 외국인의 강한 주가예측력이 외국인을 위장한 한국인의 내부자 거래로 인한 결과물일 수 있음을 의미한다. 
한국증권학회지 제49권 1호 (2020)

실제로 금융감독원도 조세피난처 외국인 거래에 대한 조사를 통해 한국인이 외국인으로 위장하여 한국 주식을 거래함을 보고하고 있다. 이들은 내부자 거래 등 불공정거래를 위해서 또는 상속 등 기업지배와 연관하여 조세피난처를 사용하고 있었다.2) 이런 행위들은 불법이며 은밀히 행하여지기 때문에 일반인들의 관심을 덜 받는 코스닥 시장 주식들에서 더 활발하게 이루어질 가능성이 많다.

본 논문은 다음과 같이 구성된다. 제 2장에서는 코스닥 시장에서 조세피난처 외국인들의 거래 현황에 대해 살펴본다. 제 3 장은 조세피난처 외국인들의 순매수금액비율을 사용하여 코스닥 시장에서의 주가예측력을 검증한다. 제 4장에서는 논문을 마무리 한다.

\section{2. 코스닥 시장에서 조세피난처 외국인 거래의 현황}

\section{1 자료}

본 연구에 필요한 분석을 위해서는 조세피난처 외국인의 한국 주식 거래내역을 산출할 수 있어야 한다. 위의 계산을 위한 주식 일중(intraday) 거래자료를 한국거래소(KRX: Korea Exchange)에서 제공받았다. 한국거래소의 일중 거래자료는 표본기간 동안 각 주식의 모든 거래에 대해 거래시간과 가격, 거래량, 매도자와 매수자의 정보를 제공하고 있다. 특히 여기에는 매도자의 매수자 각각의 국가 내역도 기록되어 있다. 한국거래소에서는 거래자의 국가에 대해서 246 개의 분류 항목를 제공하고 있다. 이 국가 정보를 사용하여 각 주식에 대해 국가별 거래내역을 파악할 수 있었다. 이 분류를 사용하여 조세피난처로부터의 외국인 거래량과 거래금액 등의 거래 내역을 계산하였다. 결과적으로, 2006년 1월부터 2009년 8월까지 코스닥 시장에서 조세피난처 외국인 거래내역을 일별로 계산하였으며 이를 사용하여 주요 분석을 진행하였다.3)

연구를 위해서 조세피난처 외국인의 거래내역 외에도 주가수익률과 기업특성변수 등 기본적인 변수들이 필요하다. 이 중 코스닥 지수 수익률과 개별주식 수익률은 자본시장연구원(KCMI) 자료를 사용하였다. 기업 규모나 장부대시장가 비율 등의 기업특성변수, 외국인 지분율은 Fn-DataGuide에서 제공받은 자료를 통해 산출하였다.

\section{2 조세피난처의 정의}

조세피난처에 대한 분석을 위해서는 한국거래소에서 제공하는 246 개국 중에서 어떤 국가를

2) 금융감독원 보도자료, 2014년 6월 17일, “위장 외국인'의 불법 증권거래 감시 강화한다”.

3) 본 연구의 표본기간(2006 2009)은 현재 시점에서 볼 때 10여 년이 지난 자료라는 약점을 가지고 있다. 하지만 외국인 투자 중에서 조세피난처 외국인이 차지하는 비중이 안정적으로 유지되고 있다는 점을 고려하면, 조세피난처 거래의 정보력이 그 기간 동안에 큰 차이가 있으리라 생각되지는 않는다. 금감원에서 2014. 6. 17. 발표한 보도자료인 “위장 외국인'의 불법 증권거래 감시 강화한다”를 보면, 2014년 4월 말 현재 금융감독원에 등록된 외국인투자자 38,437 명 중 조세회피지역에 설립된 법인은 $20 \%$ 인 7,626 명, 주식보유액 기준으로는 전체 424.2 조 원의 $11 \%$ 인 46.7 조 원을 차지하고 있음을 보고하고 있다. 본 연구에서 코스닥 시장 외국인 거래 중 조세피난처가 차지하는 비중이 $14 \%$ 정도인 것을 생각하면, 그 비중에서 큰 변화가 있다고 보기 어렵다. 
Foreign Trades from Tax Havens on the KOSDAQ

조세피난처로 분류해야하는지 실제적인 문제에 직면하게 된다. 보통 조세피난처는 소득에 대한 세금이 없거나, 낮은 세금을 부과하는 국가나 지역을 지칭한다. 우리나라는 '국제조세조정에 관한 법률'에서는 조세피난처를 '법인의 실지소득의 전부 또는 상당부분에 대하여 과세하지 아니하거나 또는 법인의 최근 3 년간 평균 부담액이 실제 발생소득의 100 분의 15 이하인 국가 또는 지역'을 정의하고 있다. 하지만, 어떤 국가나 지역이 조세피난처인지에 대한 구체적인 언급은 없다.

조세피난처에 대해 가장 큰 관심을 가져온 조직은 경제협력개발기구(OECD, Organization for Economic Cooperation and Development)이다. OECD 재정위원회는 국가 간의 유해한 조세경쟁(harmful tax competition)을 규정하고 이에 주된 역할을 하고 있는 조세피난처에 대해 규제하려는 조치들을 취하였다. 조세피난처의 존재는 국제적으로 투자를 유치하기 위해 국가 간 과도한 조세경쟁을 유발하여 각국의 재정기반을 잠식하는 것으로 인식되기 때문이다. $\mathrm{OECD}$ 노력의 결과로 2000 년 6월 처음으로 35 개 조세피난처 국가의 명단을 공표하였다. 이후 조세피난처 국가들이 유해조세제도를 개선하고 국가 간 정보교환을 약속한 협조적 조세피난처 (committed country)가 되도록 유도하고 있다(OECD, 2000). $\mathrm{OECD}$ 은 명단 작성을 통하여서 불명예를 주어 해당 국가가 이에서 벗어나게 하려는 유인을 주는 전략을 취하고 있다. 외부 조직이나 다른 국가가 한 국가의 정치나 제도에 개입을 한다는 것 차체가 실제적으로 쉽지 않고 주권침해가 될 수 있기 때문이다. 2009년 5월 $\mathrm{OECD}$ 는 조세피난처 개선을 위한 실행이 미흡한 30 개 조세피난처 명단을 다시 공개하였다. 여기에는 2000년 지정된 35 개국 중에서 건지, 저지, 세이셜, 미국령 버진아일랜드, 바베이도즈, 맨섬, 몰디브, 통가 7 개국이 제외된 반면 케이만제도, 버뮤다 2개 국가가 추가되었다. 본 연구에서는 $\mathrm{OECD}$ 의 정의에 따라서 한 번이라도 조세피난처로 언급된 아래의 37 개 국가를 조세피난처로 규정하였다.

"안도라(Andorra), 앵귈라(Anguilla), 앤티가 바부다(Antigua and Barbuda), 아루바(Aruba), 바하마 (Bahamas), 바레인(Bahrain), 벨리즈(Belize), 버뮤다(Bermuda), 영국령 버진아일랜드(British Virgin Islands), 케이맨 제도(Cayman Islands), 쿡 제도(Cook Islands), 도미니카(Dominica), 지브롤터(Gibraltar), 그레나다(Grenada), 라이베리아(Liberia), 리히텐슈타인(Liechtenstein), 마셜 제도(Marshall Islands), 모나코(Monaco), 몬세라트(Montserrat), 나우루(Nauru), 네덜란드령 안틸레스(Netherlands Antilles), 니우에(Niue), 파나마(Panama), 세인트 키츠 네비스(St. Kitts and Nevis), 세인트 루시아(St. Lucia), 세인트 빈센트 그레나딘(St. Vincent \& Grenadines), 사모아 (Samoa), 산마리노(San Marino), 터크스 케이커스 제도(Turks and Caicos Islands), 바누아투 (Vanuatu)."

이 명단에 대한 논란도 존재한다. $\mathrm{OECD}$ 가 작성한 명단에는 소위 힘없는 국가들만 포함 되어 있다는 것이다. 예를 들면, 조세피난처로 인식되기도 하는 홍콩, 싱가포르, 스위스, 룩셈부르크 등의 국가는 반대로 제외되었다는 것이다. 조세피난처에 대한 연구인 Hines and Rice(1994), Dharmapala and Hines(2009)는 스위스, 룩셈부르크 등의 나라도 조세피난처에 포함하여 분류하고 있다. 하지만, 본 연구에서는 조세피난처를 $\mathrm{OECD}$ 가 제시한 명단으로 제한하였다. 
한국증권학회지 제49권 1호 (2020)

\section{3 코스닥 시장에서 조세피난처 외국인들의 주식 거래 현황}

먼저 한국거래소 자료를 이용하여 외국인 투자자들의 거래내역을 국가별로 계산하였다. <표 1>은 표본기간인 2006년 1월부터 2009년 8월까지 3년 8개월 동안의 코스닥 시장에 상장된 모든 보통주들에 대한 외국인 거래내역을 국가별로 분류하여 보여주고 있다. 거래금액 순위 30 위까지 보고하였다. 1 위는 영국으로 총 외국인 거래금액의 $28 \%, 2$ 위는 미국으로 $15 \%, 3$ 위는 케이만제도로 $12 \%$ 이다.

\section{〈표 1〉외국인 거래의 국가별 요약통계량}

2006년 1월부터 2009년 8월(3년 8개월)까지 한국거래소 코스닥 시장에 상장된 주식들을 대상으로 외국인 국가별 거래내역을 계산하였다. 모든 외국인 거래에 대해 국가별 거래량(금액)을 합산하였다. 본 표는 매수거래금액 순서에 따라 국가를 정렬하였다.

\begin{tabular}{|c|c|c|c|c|c|c|c|c|}
\hline \multirow{3}{*}{ 국가 } & \multicolumn{3}{|c|}{ 거래량 } & \multicolumn{5}{|c|}{ 거래금액 } \\
\hline & 매수량 & 매도량 & 순매수량 & 매수금액 & 매도금액 & 순매수금액 & 합계 & 비율 \\
\hline & (백만주) & (백만주) & (백만주) & (10억원) & (10억원) & (10억원) & (10억원) & (\%) \\
\hline 영국 & 3,019 & 3,037 & -19 & 10,237 & 10,466 & -229 & 20,703 & 28.37 \\
\hline 미국 & 677 & 910 & -232 & 5,179 & 5,601 & -422 & 10,779 & 14.77 \\
\hline 케이만제도 & 397 & 682 & -285 & 3,928 & 4,495 & -567 & 8,423 & 11.54 \\
\hline 아일랜드 & 1,198 & 1,208 & -10 & 3,088 & 3,138 & -49 & 6,226 & 8.53 \\
\hline 룩셈부르크 & 63 & 72 & -8 & 1,159 & 1,218 & -59 & 2,378 & 3.26 \\
\hline 홍콩 & 141 & 247 & -105 & 1,109 & 1,218 & -110 & 2,327 & 3.19 \\
\hline 독일 & 516 & 735 & -219 & 959 & 1,264 & -305 & 2,223 & 3.05 \\
\hline 스위스 & 143 & 135 & 8 & 871 & 858 & 13 & 1,729 & 2.37 \\
\hline 싱가포르 & 97 & 98 & -1 & 535 & 495 & 40 & 1,030 & 1.41 \\
\hline 버뮤다 & 20 & 310 & -290 & 209 & 636 & -427 & 845 & 1.16 \\
\hline 네덜란드 & 24 & 40 & -16 & 327 & 378 & -51 & 705 & 0.97 \\
\hline 일본 & 59 & 76 & -16 & 300 & 341 & -42 & 641 & 0.88 \\
\hline 말레이시아 & 45 & 72 & -26 & 261 & 378 & -118 & 639 & 0.88 \\
\hline 캐나다 & 59 & 57 & 2 & 295 & 302 & -7 & 597 & 0.82 \\
\hline 오스트레일리아 & 30 & 29 & 2 & 285 & 263 & 22 & 548 & 0.75 \\
\hline 노르웨이 & 20 & 17 & 3 & 331 & 211 & 120 & 542 & 0.74 \\
\hline 프랑스 & 28 & 25 & 3 & 265 & 250 & 15 & 515 & 0.71 \\
\hline 중화민국 & 31 & 31 & 0 & 228 & 216 & 12 & 445 & 0.61 \\
\hline 미국령 버진아일랜드 & 16 & 46 & -31 & 137 & 252 & -115 & 390 & 0.53 \\
\hline 영국령 버진아일랜드 & 31 & 61 & -30 & 152 & 215 & -64 & 367 & 0.50 \\
\hline 뉴질랜드 & 19 & 22 & -3 & 195 & 168 & 27 & 363 & 0.50 \\
\hline 바하마 & 9 & 9 & 0 & 184 & 173 & 11 & 357 & 0.49 \\
\hline 중화인민공화국 & 78 & 73 & 5 & 184 & 167 & 17 & 350 & 0.48 \\
\hline 쿠웨이트 & 4 & 7 & -2 & 76 & 105 & -30 & 181 & 0.25 \\
\hline 아랍에미리트 & 2 & 4 & -2 & 69 & 93 & -23 & 162 & 0.22 \\
\hline 스웨 덴 & 6 & 7 & -1 & 78 & 77 & 1 & 154 & 0.21 \\
\hline 이탈리아 & 6 & 6 & 1 & 71 & 75 & -4 & 146 & 0.20 \\
\hline 벨기에 & 1 & 1 & 0 & 43 & 34 & 9 & 77 & 0.11 \\
\hline 사우디아라비아 & 1 & 5 & -4 & 30 & 38 & -7 & 68 & 0.09 \\
\hline 키프로스 & 2 & 2 & 0 & 27 & 38 & -11 & 64 & 0.09 \\
\hline 기타(44개국) & 223 & 294 & -72 & 4,595 & 4,400 & 195 & 8,995 & 12.33 \\
\hline 총계 & 6,968 & 8,317 & $\begin{array}{l}-1,349 \\
\end{array}$ & 35,406 & 37,564 & $-2,158$ & 72,970 & 100 \\
\hline
\end{tabular}


$<$ 표 1>의 국가들 중에서 $\mathrm{OECD}$ 가 지정한 조세피난처에 해당하는 국가는 케이만 제도, 버뮤다, 미국령 버진아일랜드, 영국령 버진아일랜드, 바하마 총 5 개이다. 본 연구에서는 분석에 사용할 조세피난처의 범위로 다음의 5 개국으로 한정하였다.

- 본 연구에서 정의한 조세피난처: 케이만제도(Cayman Islands), 버뮤다(Bermuda), 미국령 버진아일랜드(US Virgin Islands), 영국령 버진아일랜드(British Virgin Islands), 바하마 (Bahamas)

따라서 이 후부터는 위 5 개국 거래의 합을 조세피난처 거래로 정의하고 분석을 진행하였다. 외국인 총 거래금액 중에서 케이만제도는 $11.54 \%$, 버뮤다는 $1.16 \%$, 미국령 버진아일랜드가 $0.53 \%$, 영국령 버진아일랜드가 $0.50 \%$, 바하마가 $0.49 \%$ 를 차지하고 있어서, 이들을 합치면 $14.22 \%$ 에 이른다. 이 중에 주목할만한 국가는 케이만제도이다. 케이만제도로부터의 거래금액 $11.54 \%$ 는 룩셈부르크(3.26\%), 독일(3.05\%) 등 선진국의 거래금액보다도 크다는 것이다. 위의 결과들을 통하여 해당 국가 경제규모 수준 이상으로 조세피난처의 거래 규모가 큼을 확인할 수 있었다.

지금까지의 문헌에서 코스닥 기업의 외국인 투자를 국가별로 보고한 연구는 없어 보인다. 유가증권시장에 대해서는 상당한 연구들이 있다. Choe et al.(1999)은 1996년 12월부터 1997년 12 월까지 13 개월 동안의 당시 한국증권거래소(지금의 유가증권시장)의 외국인 거래량을 국가별로 보고하고 있다(<Table 2>, p. 238). Choe et al.(1999)의 경우 1 년 평균 외국인 거래금액이 약 15 조 원이다.4) 이들이 제시한 요약통계량에 따르면, 매수량 기준으로 1 위는 미국(31.1\%), 2위는 말레이시아(24.9\%), 3위는 영국(15.2\%)이었다.

Kim and Wei(2002)는 케이만, 버뮤다 등의 조세피난처 역외펀드 133개가 1999년 12월 말에 한국 주식 1 조 5 천억 원 정도의 보유포지션을 가지고 있음을 보고하고 있다(<Table $1>$, p. 209). 금융감독원은 2014년 4월 말 주식보유액 기준으로 외국인이 보유한 전체 424조 3천억 원의 주식 중에서 $11 \%$ 인 46 조 7 천억 원 정도를 조세피난처에 설립된 법인이 보유하고 있음을 보고하고 있다.5)

Yang(2015a)는 2006년 1월부터 2008년 6월(2년 6개월)까지의 유가증권시장의 외국인 거래를 국가별로 집계하여 보고하고 있다. 이들이 제시한 통계량에 의하면, 매수량 기준 1 위는 영국, 2 위는 미국, 3 위는 케이만제도였으며, 본 연구에서 보여준 코스닥 시장과 순위가 같다. 유가증권 시장에서 1 년 평균 외국인 거래금액은 $(684$ 조 +737 조 $) / 2.5$ 년 $=568$ 조였다. 본 연구에서 코스닥 시장의 1 년 평균 외국인 거래금액은 $(35$ 조 +38 조 $) / 3.7$ 년 $=20$ 조 정도이다. 유가증권시장과 코스닥 시장을 비교하면, 2006 년 기준 시가총액은 유가증권시장이 코스닥 시장의 10 배 정도이며, 일 평균 거래금액은 3 배 정도이다. 따라서 코스닥 시장의 시가총액 회전율 $628 \%$ 로 유가증권시장의 $129 \%$ 보다 훨씬 높다. 외국인 지분율은 유가증권시장이 $37.26 \%$ 로 코스닥 시장 $14.64 \%$ 보다 크다.

4) 1 년 평균 외국인 거래금액은 (684조+737조)/2.5년 =568조이며, Choe et al.(1999)는 거래금액을 달러화로 표시하고 있는데, 간단히 1 달러를 1,000 원으로 환산하여 계산하였다.

5) 금융감독원 보도자료, 2014년 6월 17일, “위장 외국인”의 불법 증권거래 감시 강화한다”. 
한국증권학회지 제49권 1호 (2020)

<그림 2>는 조세피난처 5개국 순매수금액의 시계열을 보여주고 있다. 모든 종목으로부터의 일별 순매수금액 합계를 막대그래프로 표시하였으며, 해당 일의 KOSDAQ 지수를 동시에 보여주고 있다. 전반적으로 조세피난처 외국인들의 순매도 거래일이 순매수 거래일보다 많음을 확인할 수 있다. 특히 막대그래프가 큰 순매도(음의 순매수) 값을 가지는 2007년 후반기는 $\mathrm{KOSDAQ}$ 지수가 상승세에서 하락세로 돌아서는 기간과 일치한다. 반대로 막대그래프가 양(+)의 값으로 크게 돌출되는 2006년 4월, 2007년 6월, 8 10월 등의 기간은 조세피난처로부터의 순매수가 상승하며 $\mathrm{KOSDAQ}$ 지수도 상승하고 있지만 그 기간이 길지는 않다.

〈그림 2〉 코스닥 시장에서 조세회피처의 순매수 거래금액 추이

본 그림은 코스닥 시장에서 표본기간 2006년 1월부터 2009년 8월까지 조세피난처 외국인의 일별 순매수 금액의 추이를 보여주고 있다. 조세피난처로 5 개국(케이만제도, 버뮤다, 바하마, 미국령 버진아일랜드, 영국령 버진아일랜드)을 정의하였다. 막대그래프는 한국거래소 코스닥 시장의 모든 상장 주식에 대해 조세피난처 외국인들의 순매수금액의 총합을 일별로 보여주고 있다. 추세선은 일별 KOSDAQ 지수이다.

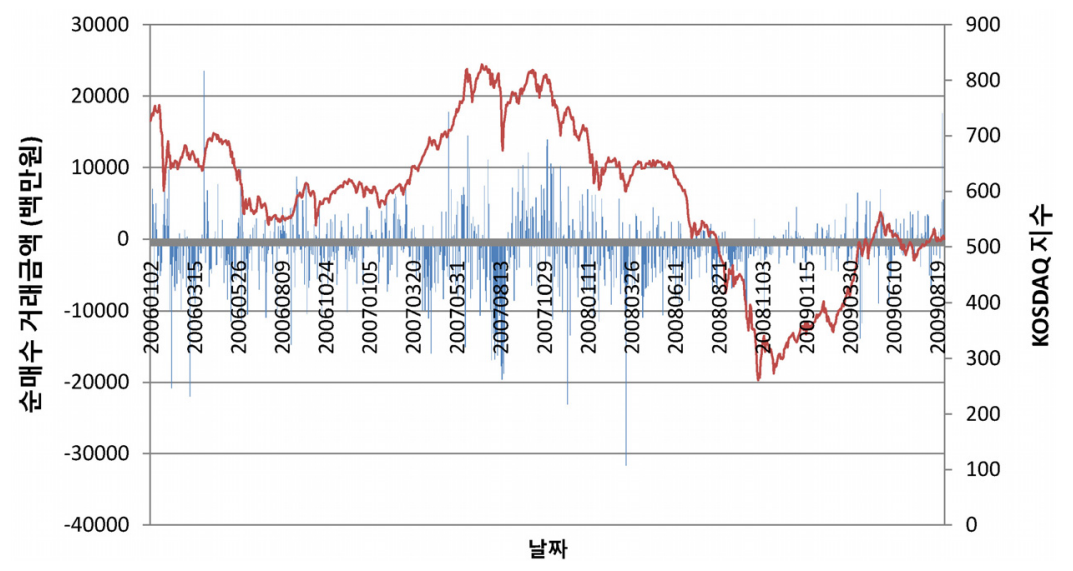

<표 2>는 조세피난처 외국인의 거래가 존재하는 기업들의 기업특성변수와 일별 거래내역에 대한 요약통계량을 보고하고 있다. 앞 절에 근거하여 케이만제도, 버뮤다, 미국령 버진아일랜드, 영국령 버진아일랜드, 바하마 5개국을 조세피난처로 정의하고 위 국가로부터의 거래의 합을 조세피난처 거래로 집계하였다. 한국거래소 코스닥 시장의 상장 기업들을 대상으로 하여 일별로 조세피난처 외국인 거래를 계산하였다. 즉, 각 기업별, 그리고 거래일별로 조세피난처 5 개국으로 부터의 순매수거래금액을 계산하였다. 그 결과 표본기간 동안 총 735 개 종목에 대해 조세피난처 외국인 거래가 존재하였다.

<표 2>의 패널 $\mathrm{A}$ 는 위의 735 개 표본기업들의 요약통계량을 보여준다. 이들 기업규모의 평균은 9 백억 원이며, 중간값은 약 5 백억 원이다. 기업규모가 1 조 8 천억 원에 이르는 대규모 기업들도 표본이 구성되어 있지만, 최소값이 약 2 억 원, 일사분위(Q1)이 약 3 백억 원인 것을 볼 때에 상당수 작은 규모의 기업들도 표본에 포함됨을 볼 수 있다. 장부가대시장가는 평균이 0.79 이며, 최소값이 -16.42 이다. 이는 자본잠식된 기업들도 표본에 포함되어 있음을 의미한다. 외국인 지분율의 평균은 $4.73 \%$ 이며 중간값은 $1.37 \%$ 이다. 
Foreign Trades from Tax Havens on the KOSDAQ

각 기업에 대하여 일별 조세피난처 거래내역을 집계하였을 때 735 개 기업에 대해서 총 30,292 기업-일 관측치를 얻을 수 있었다. 이 변수들의 요약통계량을 <표 $2>$ 의 패널 $\mathrm{B}$ 에 보고하였다. <표 2>의 패널 B에서 일별 순매수량의 평균은 $-22,493$ 주이며, 순매수금액의 평균은 $-44,284$ 천 원이다. 일별 조세피난처 순매수량(금액)비율의 평균은 $-2.45 \%$ 이다. 순매수량(금액)비율의 중간값도 역시 음(-)의 값을 가지고 있다. 표본기간 동안 조세피난처 외국인들이 매도한 금액이 매수한 금액을 초과한 거래일이 많았음을 보여준다. 즉, 조세피난처 외국인들의 거래가 매도 쪽으로 기운 거래일이 더 많았다는 것이다. 순매수량의 최소값 -5 백 40 만주도 최대값은 3 백 50 만주보다 규모에서 크다. 거래금액에서도 최소값이 최대값보다 크다. 이는 대규모의 순매도를 보인 거래일의 거래규모가 순매수 경우보다 월등하게 큼을 의미한다.

\section{〈표 2〉 조세피난처 외국인 거래의 요약통계량}

조세피난처로 케이만제도, 버뮤다, 바하마, 미국령 버진아일랜드, 영국령 버진아일랜드 5 개국을 정의하였다. 표본기간 2006년 1월부터 2009년 8월(3년 8개월)동안 조세피난처 외국인 거래가 존재하는 기업은 총 735 개이다. 본 표의 패널 $\mathrm{A}$ 는 이들 기업 특성변수들의 횡단면 분포를 제시한다. 기업규모는 연말의 종가에 상장주식수를 곱한 값이며, 2006년부터 2009년의 평균값을 구하였다. 장부가대시장가(BM)는 연말의 자본총계를 시장가치로 나눈 값이며, 2006년부터 2009년의 평균값을 구하였다. 외국인 지분율은 $\mathrm{Fn}$ DataGuide에서 추출하였으며 2006년부터 2009년의 평균값을 사용하였다. 위의 표본기업에 대해 일별로 조세피난처 외국인 거래내역을 계산하였을 때 최종적으로 30,292 개 기업-일의 관측치를 얻었으며, 패널 $\mathrm{B}$ 는 위의 조세피난처 외국인의 거래활동의 분포를 보여주고 있다. 순매수량은 해당 거래일의 조세피난처 매수주식수에서 매도주식수를 차감하였으며, 순매수금액은 해당 거래일의 조세피난처 매수금액에서 매도금액을 차감하였다. 순매수량비율은 해당 거래일의 순매수량을 주식 일별 거래량으로 나눈 비율이며, 순매수금액비율은 해당 거래일의 순매수금액을 주식 일별 거래금액으로 나눈 비율이다.

패널 $\mathrm{A}$ : 표본기업의 요약통계량

\begin{tabular}{lrrrrrrr}
\hline & 평균 & 표준편차 & 최소값 & \multicolumn{1}{c}{$\mathrm{Q} 1$} & 중간값 & \multicolumn{1}{c}{$\mathrm{Q} 3$} & \multicolumn{1}{c}{ 최대값 } \\
\hline 기업규모(백만원) & 90,055 & 137,277 & 232 & 29,696 & 52,197 & 99,839 & $1,770,023$ \\
장부가대시장가 & 0.79 & 1.34 & -16.42 & 0.45 & 0.74 & 1.17 & 5.73 \\
외국인 지분율(\%) & 4.73 & 8.06 & 0.00 & 0.23 & 1.37 & 5.22 & 59.41 \\
\hline
\end{tabular}

패널 $\mathrm{B}$ : 조세피난처 외국인의 일별 거래내역의 요약통계량

\begin{tabular}{lrrrrrrr}
\hline & \multicolumn{1}{c}{ 평균 } & 표준편차 & 최소값 & \multicolumn{1}{c}{$\mathrm{Q} 1$} & \multicolumn{1}{c}{ 중간값 } & \multicolumn{1}{c}{$\mathrm{Q} 3$} & \multicolumn{1}{c}{ 최대값 } \\
\hline 순매수량(주) & $-22,493$ & 179,101 & $-5,354,202$ & $-15,000$ & $-1,000$ & 4,955 & $3,500,000$ \\
순매수금액(천원) & $-44,284$ & 734,351 & $-21,644,908$ & $-145,270$ & $-11,322$ & 68,911 & $18,648,769$ \\
순매수량비율(\%) & -2.45 & 17.76 & -100.00 & -9.45 & -0.68 & 3.76 & 99.98 \\
순매수금액비율(\%) & -2.45 & 17.75 & -100.00 & -9.43 & -0.68 & 3.76 & 99.98 \\
거래량(주) & $1,737,853$ & $3,440,262$ & 482 & 214,492 & 510,021 & $1,873,734$ & $49,627,962$ \\
거래금액(천원) & $6,340,825$ & $12,412,227$ & 13,050 & $1,217,028$ & $2,852,816$ & $6,543,222$ & $171,452,678$ \\
\hline
\end{tabular}

다음은 코스닥 시장에서 조세피난처 외국인들에 의해 가장 활발하게 거래되는 종목들을 살펴 보았다. 표본기간 중에 하루 이상 조세피난처 외국인 거래가 존재하는 종목은 735 개이다. 조세피난처로부터의 외국인 거래활동을 측정하기 위해, 각 종목의 3 년 8개월 표본기간 동안의 모든 거래금액의 합계를 구한 후에 2006년 2009년 말의 평균 시가총액으로 나누어서 표준화 
한국증권학회지 제49권 1호 (2020)

하였다. 위의 연평균 거래금액 대 시가총액 순서로 기업들을 정렬하였다. <표 $3>$ 은 시가총액 대비 조세피난처 외국인 거래가 가장 활발한 상위 20 개 종목을 보고하고 있다. 코스닥 기업의 특성상 IT기업이 많음을 확인할 있다. $\mathrm{VK}$, 에임하이, 일경산업개발, 디지텍시스템, 알에스넷, 포휴먼, 엘앤피아너스, 네이쳐글로벌 등의 회사는 전자 및 전기 제조업체로서 IT기업이라고 할 수 있다. 플레이위드는 게임 컨텐츠 업체이며, 이화공영, IC코퍼레이션은 건설업체이다. 오스템 임플란트는 의료용 기기 제조업체이며, 홈센타는 시멘트, 석회, 플라스터 및 그 제품 제조업을 영위하고 있다. 예당은 엔터테인먼트 사업을 하고 있다. C\&S자산관리는 종합 건물관리회사로서 시설, 경비, 청소, 주차, 안내, 방역업무를 한다. 에스피코프는 종합도매업, $\mathrm{HRS}$ 는 실리콘고무 생산업체이다.

〈표 3〉 조세피난처 외국인의 거래금액 상위 기업

조세피난처로 케이만제도, 버뮤다, 바하마, 미국령 버진아일랜드, 영국령 버진아일랜드 5 개국을 정의하였다. 표본기간 2006년 1월부터 2009년 8월(3년 8개월, 총 909일)동안 조세피난처로부터의 외국인 거래가 존재하는 주식은 총 735 종목이다. 각 주식의 표본기간 동안의 조세피난처 외국인의 연평균 거래금액을 2006년 2009년 평균 시가총액으로 나눈 비율을 구한 후에, 이 비율의 상위 20개 기업을 보고하였다. 해당 기업의 표본기간 동안의 조세피난처 외국인 거래의 총 순매수량과 순매수금액도 제시하였다.

\begin{tabular}{|c|c|c|c|c|c|c|}
\hline 순위 & 기업 & $\begin{array}{c}\text { 연평균 거래금액/ } \\
\text { 시가총액(\%) }\end{array}$ & $\begin{array}{l}\text { 거래금액 } \\
\text { (백만원) }\end{array}$ & $\begin{array}{l}\text { 시가총액 } \\
\text { (백만원) }\end{array}$ & $\begin{array}{l}\text { 순매수량 } \\
\text { (천주) }\end{array}$ & $\begin{array}{l}\text { 순매수금액 } \\
\text { (백만원) }\end{array}$ \\
\hline 1 & VK & 6,099 & 247,769 & 1,108 & $-11,186$ & $-9,353$ \\
\hline 2 & 플레이위드 & 857 & $1,390,207$ & 44,232 & 1,375 & 21,124 \\
\hline 3 & 팬텀엔터그룹 & 764 & $1,212,213$ & 43,254 & -380 & $-7,246$ \\
\hline 4 & 이화공영 & 693 & $2,200,121$ & 86,627 & -3 & -258 \\
\hline 5 & 에임하이 & 676 & 961,937 & 38,822 & $-20,541$ & $-23,854$ \\
\hline 6 & 일경산업개발 & 605 & 510,237 & 23,009 & -940 & $-2,576$ \\
\hline 7 & 알에스넷 & 525 & 304,174 & 15,815 & 0 & 43 \\
\hline 8 & 오스템임플란트 & 511 & $4,736,607$ & 253,033 & 313 & $-3,259$ \\
\hline 9 & 홈센타 & 453 & 953,316 & 57,361 & $-2,030$ & $-3,286$ \\
\hline 10 & 예당 & 420 & $1,401,428$ & 90,963 & $-1,713$ & $-2,579$ \\
\hline 11 & IC코퍼레이션 & 408 & 480,289 & 32,077 & $-29,183$ & $-19,192$ \\
\hline 12 & 포휴먼 & 399 & $3,409,626$ & 233,312 & 413 & 22,339 \\
\hline 13 & 디지텍시스템 & 397 & $3,799,561$ & 260,791 & -420 & 3,011 \\
\hline 14 & C\&S자산관리 & 393 & $1,007,808$ & 69,905 & $-3,450$ & $-9,267$ \\
\hline 15 & 에스피코프 & 393 & 305,800 & 21,239 & 396 & 2,723 \\
\hline 16 & 다휘 & 380 & 464,308 & 33,283 & -264 & $-2,578$ \\
\hline 17 & HRS & 363 & 953,387 & 71,614 & -3 & -365 \\
\hline 18 & 휘튼 & 360 & 15,413 & 1,168 & $-3,210$ & $-3,083$ \\
\hline 19 & 엘앤피아너스 & 351 & 560,182 & 43,485 & $-1,443$ & $-6,258$ \\
\hline 20 & 네이쳐글로벌 & 336 & 340,495 & 27,643 & -512 & $-2,311$ \\
\hline
\end{tabular}

이들 중 에는 상장폐지된 업체들이 많다. 1 위인 VK도 2006년 7월 7일, 영업 손실에서 비롯된 자금난으로 인해 파산하였으며, 2009년 12 월 수원지방법원으로부터 회생절차 폐지 결정을 받고 
Foreign Trades from Tax Havens on the KOSDAQ

청산되었다.6) 포휴먼은 2011년 4월 사업보고서 미제출의 이유로 상장폐지되었다. 에스피코프 2010년 3월 감사의견 거절로 상장폐지되었다. 다휘는 산업용 오븐 및 환경오염방지기술 개발 업체였으나 대표이사들이 횡렴혐의로 고소되는 일이 생기면서 상장폐지실질심사를 거쳐 2010년 10 월 상장폐지되었다. 엘앤피아너스는 대표이사가 세 차례의 유상증자 과정에서 주가조작을 한 혐의로 처벌을 받았으며, 2011년 상장폐지되었다.

\section{3. 조세피난처 거래의 주가예측력}

\section{1 연구 설계}

본 장에서는 조세피난처 거래의 주가예측력을 검증하기 위한 연구설계를 설명한다. 주가예측력 검증을 위해 재무 분야에서 일반적으로 사용하는 포트폴리오 분석과 회귀분석 방법을 사용하였다. 회귀분석은 수익률과 변수와의 선형관계를 직접적으로 검증한다. 하지만, 주가예측력이라는 것이 반드시 둘 간의 선형관계로 성립하는 것은 아니다. 포트폴리오 접근법은 관심있는 변수로 포트폴리오를 구성한 후의 포트폴리오의 수익률을 검증하는 방식이다. 따라서 관심변수의 주가예측력을 광범위하게 검증할 수 있는 장점이 있다. 또한 실제 투자자 입장에서 사용할 수 있는 전략이기 때문에 주가예측력의 크기를 더 실제적으로 이해할 수 있다.

먼저 포트폴리오를 사용한 주가예측력 검증 방법에 대하여 설명하고자 한다. 조세피난처 외국인의 순매수금액비율에 따라 정렬된 포트폴리오의 수익률을 검증하는 방법을 사용하였다. 구체적인 진행 절차는 다음과 같다. 첫째, 거래일 $\mathrm{t}$ 일을 기준으로 하여 각 주식을 해당 주식의 조세피난처 순매수금액비율로 정렬하여 포트폴리오 5 개를 구성한다. 해당 주식의 순매수금액 비율은 주식의 조세피난처 외국인들의 일별 매수금액에서 매도금액을 차감한 값을 주식 일별 거래금액으로 나누어서 구하였다. 조세피난처 외국인이 매도한 금액이 많을수록 순매수금액 비율은 작아져 음(-)의 값을 지닐 것이며, 반대로 매수한 금액이 많을수록 양(+)의 값을 지니게 된다. 거래일 $\mathrm{t}$ 일의 포트폴리오는 해당일에 조세피난처 거래가 존재하는 주식들만을 대상으로 하여 5 개로 구성하였다. 따라서 매 거래일 포트폴리오를 구성하는 주식들의 종목수가 동일하지는 않다.7)

둘째, 거래일 $\mathrm{t}$ 일에 구성한 5 개 포트폴리오들의 다음날 $\mathrm{t}+1$ 거래일의 수익률을 산출한다. 포트폴리오의 수익률은 포함된 주식들의 수익률을 단순평균하여 계산하였다. 동일한 포트폴리오에 대해서 $\mathrm{t}+1$ 일부터 2 일 동안의 보유수익률 $(\mathrm{t}+1 \sim \mathrm{t}+2)$ 도 구하였으며, 보유기간을 늘리면서 5 일까지의 보유수익률 $(\mathrm{t}+1 \sim \mathrm{t}+5)$ 을 산출하였다. 결국 각 포트폴리오에 대해 1 일부터 5 일까지 5종류의 보유수익률을 계산한 것이다.

6) VK는 휴대전화 단말기 제조사로서 VK(Viable Korea)라는 브랜드로 2001년에는 자사의 휴대전화를 생산하기 시작하였고 초기에는 성공적이었지만 이후 경영난으로 상장폐지되었다.

7) 포트폴리오 구성 시, 표본기간 909일에서 포트폴리오 종목수의 최소값은 3 개, 중간값은 32 개, 최대값은 75 개이며, 평균은 33 개입니다. 평균을 기준으로 하면, 5 개의 그룹을 나누었을 때 한 포트폴리오에 평균적으로 6 7개 종목이 포함되어 있다. 
한국증권학회지 제49권 1호 (2020)

마지막으로 조세피난처 순매수금액비율이 가장 낮은 포트폴리오를 공매도하고 가장 높은 포트폴리오는 매수하는 헤지포트폴리오(High-Low)를 구성한 후에 이후 1일부터 5일까지의 보유수익률을 산출하였다.

연구의 가설 1 과 같이 조세피난처 거래가 주가예측력을 지닌다면, 첫째 조세피난처 순매수 비율이 높은 포트폴리오일수록 높은 수익률을 가질 것이다. 즉, 조세피난처 외국인들이 매도하는 종목일수록 수익률이 낮으며, 반대로 조세피난처 외국인들이 매수하는 종목일수록 수익률은 높을 것이다. 둘째, 조세피난처 순매수비율이 가장 낮은 포트폴리오를 공매도하고 가장 높은 포트폴리오를 매수는 헤지포트폴리오가 유의적인 양(+)의 수익률을 보여야 할 것이다.

위의 포트폴리오 정렬방법을 사용한 접근방법의 유의한 결과가 반드시 조세피난처 거래와 주가수익률의 선형적인 관계를 의미하지는 않는다. 추가 분석에서는 회귀분석을 사용하여 개별 주식의 조세피난처 순매수금액비율과 주식 수익률의 선형관계도 검증하고자 하였다. 회귀분석의 종속변수로 개별 주식의 $\mathrm{t}+1$ 일의 수익률을, 독립변수로는 $\mathrm{t}$ 일의 조세피난처 순매수금액비율을 사용하였다. 구체적인 회귀분석식은 다음과 같다.

$$
\operatorname{Return}_{i, t+1}=\alpha+\beta N T_{i, t}+\gamma \operatorname{Return}_{i, t}+\delta \text { Size }_{i, t}+\theta B M_{i, t}+\epsilon_{i, t}
$$

여기서, $\operatorname{Return}_{i, t+1}$ 은 주식 $\mathrm{i}$ 의 $\mathrm{t}+1$ 일 수익률이며, $N T_{i, t}$ 는 주식 $\mathrm{i}$ 의 $\mathrm{t}$ 일의 조세피난처 외국인의 순매수금액비율(Net Trading)이다. 통제변수로는 t일의 각 주식의 수익률(Return)과 기업규모 (Size), 장부가대시장가(BM)를 추가하였다.

\section{2 포트폴리오 분석 결과}

$<$ 표 4>는 조세피난처 외국인 순매수금액비율에 따른 포트폴리오의 수익률을 보여주고 있다. $\mathrm{t}+1$ 일의 수익률을 보면 순매수금액이 가장 낮은 포트폴리오(Low)의 수익률 $-0.18 \%$ 이며, 그 다음 Q2와 Q3가 $-0.23 \%$ 로 오히려 감소한다. 하지만, Q4와 가장 높은 포트폴리오(High)의 수익률이 각각 $0.20 \%, 0.43 \%$ 로 계속해서 증가한다. 5 개의 포트폴리오들 중에서 주목할 만한 것은 조세피난처 순매수금액비율이 가장 높은 포트폴리오(High)이다. 이의 $\mathrm{t}+1$ 일 수익률은 $0.43 \%$ 이며 통계적으로도 유의하다. 보유기간을 늘렸을 때도 4 일까지 수익률이 계속 증가하며 모두 유의미하다. 이런 현상은 다른 4 개의 포트폴리오들에서는 발견할 수 없으며 조세피난처 외국인들이 보유한 좋은 뉴스의 정보력이 상당기간 유효함을 의미한다. 반면, LOW 포트폴리오의 $\mathrm{t}+1$ 일 수익률은 $-0.18 \%$ 로서 통계적으로 유의하지만, 보유기간이 늘어나면 유의성은 사라진다. 그 이유 중 하나로 공매도에 대한 제약을 생각할 수 있다. 투자자가 부정적 정보를 이용하여 이익을 얻으면 공매도 포지션을 취해야 한다. 하지만, 공매도는 거래비용이 크며 규제가 많기 때문에 매수에 비해 실행하는 데 있어서 더 큰 제약이 따른다.

조세피난처 외국인의 순매수금액비율이 가장 낮은 포트폴리오를 공매도하고 가장 높은 포트 폴리오를 매수하는 헤지포트폴리오(High-Low)의 수익률은 $0.61 \%(\mathrm{t}-$ 값 $=7.80)$ 이며 통계적으로 유의하다. 월 거래일을 22 일로 생각하면, 헤지포트폴리오의 수익률은 월 $13.42 \%$ 가 된다. Yang (2015b)의 연구에서 유가증권시장을 대상으로 동일한 분석을 하였을 때 헤지포트폴리오 수익률은 일 평균 $0.28 \%$ (월 $6.2 \%$ )였다. 
Foreign Trades from Tax Havens on the KOSDAQ

위 수익률을 간단한 벤치마크와 비교하였다. 표본기간 2006년 1월부터 2009년 8월 동안의 코스닥 시장 수익률과 무위험 이자율을 벤치마크로 사용하면, 코스닥 지수는 일평균 $-0.016 \%$ 수익률을, 무위험 자산은 일평균 $0.013 \%$ 수익률을 주었다. 이에 비교하여도 조세피난처 순매수 금액비율의 헤지포트폴리오 $0.61 \%$ 는 상당히 높은 수익률임을 알 수 있다.

〈표 4〉 조세피난처 외국인의 순매수금액비율로 정렬한 포트폴리오의 보유수익률(\%) 조세피난처로 케이만제도, 버뮤다, 바하마, 미국령 버진아일랜드, 영국령 버진아일랜드 5 개국을 정의하였다. 표본기간은 2006년 1월부터 2009년 8월(3년 8개월)이다. 거래일 t일에 주식의 조세피난처 순매수금액비율에 따라 정렬하여 5 개 포트폴리오를 구성한 후, 다음 거래일 $\mathrm{t}+1$ 일의 수익률을 계산한다. 포트폴리오는 매일 재조정된다. 그리고 다음 거래일부터 2 일 동안의 보유수익률 $(\mathrm{t}+1 \sim \mathrm{t}+2)$ 에서 시작하여 5 일까지의 보유 수익률 $(\mathrm{t}+1 \sim \mathrm{t}+5)$ 을 각각 계산하였다. High-Low는 조세피난처 순매수금액비율이 가장 낮은 포트폴리오를 공매도하고 가장 높은 포트폴리오는 매수하는 헤지포트폴리오의 보유수익률이다. 괄호 안은 $\mathrm{t}$-값을 제시한다.

\begin{tabular}{lcccccc}
\hline & Low & Q2 & Q3 & Q4 & High & High-Low \\
\hline HPR $_{\mathrm{t}+1}$ & $-0.18(-2.21)$ & $-0.23(-2.70)$ & $-0.23(-2.42)$ & $0.20(2.30)$ & $0.43(5.40)$ & $0.61(7.80)$ \\
$\mathrm{HPR}_{\mathrm{t}+1 \sim \mathrm{t}+2}$ & $-0.15(-1.25)$ & $-0.21(-1.65)$ & $-0.31(-2.30)$ & $0.11(0.87)$ & $0.57(4.94)$ & $0.72(6.41)$ \\
$\mathrm{HPR}_{\mathrm{t}+1 \sim \mathrm{t}+3}$ & $-0.09(-0.61)$ & $-0.20(-1.27)$ & $-0.31(-1.85)$ & $0.04(0.25)$ & $0.57(3.92)$ & $0.66(4.58)$ \\
$\mathrm{HPR}_{\mathrm{t}+1 \sim \mathrm{t}+4}$ & $-0.04(-0.21)$ & $-0.19(-1.04)$ & $-0.30(-1.52)$ & $0.06(0.30)$ & $0.64(3.67)$ & $0.68(3.93)$ \\
HPR $_{\mathrm{t}+1 \sim \mathrm{t}+5}$ & $0.09(0.47)$ & $-0.21(-1.02)$ & $-0.30(-1.31)$ & $0.05(0.26)$ & $0.53(2.69)$ & $0.44(2.25)$ \\
\hline
\end{tabular}

투자전략의 보유기간을 2일 $(\mathrm{t}+1 \sim \mathrm{t}+2)$ 로 증가시켰을 때, 포트폴리오의 조세피난처 순매수금액 비율이 증가할수록 수익률이 증가하는 경향을 보였으며 헤지포트폴리오의 수익률도 $0.72 \%$ 로 통계적 유의성이 유지되었다. 보유기간을 5 일까지 늘렸을 경우에는 수익률이 약간 하락하나 여전히 통계적으로 유의하였다. 위의 포트폴리오 수익률의 결과들은 코스닥 시장에서 조세피난처 순매수금액비율이 유의미한 주가예측력을 가짐을 보여준다. 또한 본 연구에서 보여주는 코스닥 시장에서의 헤지포트폴리오 수익률은 유가증권시장에서의 2 배 정도에 해당한다. 이는 코스닥 시장에 들어오는 조세피난처 외국인들이 거래의 주가예측력이 유가증권시장보다 더 강함을 의미한다.

다음은 포트폴리오의 위험 조정 수익률을 살펴보고자 한다. 재무분야에서 가장 널리 사용되는 $\mathrm{CAPM}$ 을 사용하여 위험을 통제하였다. 각 포트폴리오에 대하여 다음의 회귀분석을 시행 하였다.

$$
R_{p, t}=\alpha_{p}+\beta_{p} \text { Market }_{\mathrm{t}}+\epsilon_{\mathrm{p}, \mathrm{t}}
$$

여기서, $R_{p, t}$ 는 포트폴리오 $\mathrm{p}$ 의 t일의 초과수익률을, Market $\mathrm{t}$ 은 $\mathrm{t}$ 일의 KOSDAQ지수의 초과수익률을 나타낸다. 위의 시계열 회귀분석을 조세피난처 순매수금액비율로 정렬한 5 개의 포트폴리오와 헤지포트폴리오를 대상으로 하여 시행하였다. 여기서 주된 관심은 시계열 회귀 분석의 절편값 즉, 위험을 조정한 후의 초과수익률이다. 이를 ALPHA 값이라고 부르는데, 분석에서는 포트폴리오들의 ALPHA 값의 유의성을 확인하였다. 
한국증권학회지 제 49 권 1 호 (2020)

또한 Fama and French(1993)의 3요인 모형과 Fama and French(2015)의 5요인 모형을 사용한 포트폴리오의 ALPHA 값도 확인하였다.

$$
\begin{aligned}
& R_{p, t}=\alpha_{p}+\beta_{p} \text { Market }_{\mathrm{t}}+\gamma_{\mathrm{p}} \mathrm{SMB}_{\mathrm{t}}+\delta_{\mathrm{p}} \mathrm{HML}_{\mathrm{t}}+\epsilon_{\mathrm{p}, \mathrm{t}} \\
& R_{p, t}=\alpha_{p}+\beta_{p} \text { Market }_{\mathrm{t}}+\gamma_{\mathrm{p}} \mathrm{SMB}_{\mathrm{t}}+\delta_{\mathrm{p}} \mathrm{HML}_{\mathrm{t}}+\zeta_{\mathrm{p}} \mathrm{RMW}_{\mathrm{t}}+\eta_{\mathrm{p}} \mathrm{CMA}_{\mathrm{t}}+\epsilon_{\mathrm{p}, \mathrm{t}}
\end{aligned}
$$

여기서, $\mathrm{SMB}_{\mathrm{t}}$ 는 $\mathrm{t}$ 일의 규모요인을, $\mathrm{HML}_{\mathrm{t}}$ 은 $\mathrm{t}$ 일의 장부가대시장가요인(가치요인)을, $\mathrm{RMW}_{\mathrm{t}}$ 는 t일의 수익성요인을, $\mathrm{CMA}_{\mathrm{t}}$ 은 $\mathrm{t}$ 일의 투자요인을 나타낸다.

〈표 5〉 조세피난처 외국인의 순매수금액비율로 정렬한 포트폴리오의 위험조정 수익률(\%) 조세피난처로 케이만제도, 버뮤다, 바하마, 미국령 버진아일랜드, 영국령 버진아일랜드 5 개국을 정의하였다. 표본기간은 2006년 1월부터 2009년 8월(3년 8개월)이다. 거래일 t일에 주식의 조세피난처 순매수금액비율에 따라 정렬하여 5 개 포트폴리오를 구성한 후, 다음 거래일 $\mathrm{t}+1$ 일의 수익률을 계산한다. 포트폴리오는 매일 재조정된다. 그리고 다음 거래일부터 2 일 동안의 보유수익률 $(\mathrm{t}+1 \sim \mathrm{t}+2)$ 에서 시작하여 5 일까지의 보유 수익률 $(\mathrm{t}+1 \sim \mathrm{t}+5)$ 을 각각 계산하였다. High-Low는 조세피난처 순매수금액비율이 가장 낮은 포트폴리오를 공매도하고 가장 높은 포트폴리오는 매수하는 헤지포트폴리오의 보유수익률이다. 패널 A는 CAPM, 패널 B는 Fama-French(1993) 3요인 모형, 패널 C는 Fama-French(2015) 5요인 모형을 사용한 위험조정 수익률, 즉 $\mathrm{ALPHA}$ 값을 보여주고 있다. 괄호 안은 $\mathrm{t}$-값을 제시한다.

패널 $\mathrm{A}: \mathrm{CAPM}$ 조정 수익률

\begin{tabular}{lrccccc}
\hline & Low & Q2 & Q3 & Q4 & High & High-Low \\
\hline ALPHA $_{t+1}$ & $-0.15(-2.68)$ & $-0.20(-3.53)$ & $-0.19(-3.21)$ & $0.24(4.03)$ & $0.46(8.33)$ & $0.61(7.78)$ \\
ALPHA $_{t+1 \sim t+2}$ & $-0.12(-1.16)$ & $-0.17(-1.64)$ & $-0.27(-2.47)$ & $0.15(1.40)$ & $0.60(6.26)$ & $0.72(6.39)$ \\
ALPHA $_{t+1 \sim t+3}$ & $-0.06(-0.42)$ & $-0.16(-1.15)$ & $-0.27(-1.82)$ & $0.08(0.56)$ & $0.61(4.61)$ & $0.66(4.57)$ \\
ALPHA $_{t+1 \sim t+4}$ & $0.00(0.00)$ & $-0.15(-0.90)$ & $-0.26(-1.43)$ & $0.10(0.56)$ & $0.68(4.17)$ & $0.68(3.93)$ \\
ALPHA $_{t+1 \sim t+5}$ & $0.13(0.69)$ & $-0.17(-0.89)$ & $-0.26(-1.20)$ & $0.09(0.47)$ & $0.57(3.03)$ & $0.44(2.24)$ \\
\hline
\end{tabular}

패널 B: Fama-French 3요인 모형 조정 수익률

\begin{tabular}{lrccccc}
\hline & Low & Q2 & Q3 & Q4 & High & High-Low \\
\hline ALPHA $_{t+1}$ & $-0.17(-2.00)$ & $-0.23(-2.57)$ & $-0.21(-2.14)$ & $0.21(2.36)$ & $0.41(4.96)$ & $0.57(7.13)$ \\
ALPHA $_{t+1 \sim t+2}$ & $-0.07(-0.60)$ & $-0.19(-1.45)$ & $-0.26(-1.88)$ & $0.15(1.14)$ & $0.55(4.67)$ & $0.63(5.45)$ \\
ALPHA $_{t+1 \sim t+3}$ & $-0.01(-0.03)$ & $-0.19(-1.16)$ & $-0.26(-1.48)$ & $0.13(0.76)$ & $0.55(3.70)$ & $0.56(3.76)$ \\
ALPHA $_{t+1 \sim t+4}$ & $0.06(0.35)$ & $-0.19(-0.99)$ & $-0.24(-1.19)$ & $0.13(0.69)$ & $0.60(3.36)$ & $0.54(3.05)$ \\
ALPHA $_{t+1 \sim t+5}$ & $0.22(1.08)$ & $-0.18(-0.83)$ & $-0.21(-0.92)$ & $0.15(0.71)$ & $0.53(2.59)$ & $0.30(1.51)$ \\
\hline
\end{tabular}

패널 C: Fama-French 5요인 모형 조정 수익률

\begin{tabular}{lrccccc}
\hline & Low & Q2 & Q3 & Q4 & High & High-Low \\
\hline ALPHA $_{t+1}$ & $-0.16(-1.98)$ & $-0.23(-2.53)$ & $-0.20(-2.10)$ & $0.21(2.33)$ & $0.40(4.89)$ & $0.57(7.14)$ \\
ALPHA $_{t+1 \sim t+2}$ & $-0.07(-0.59)$ & $-0.18(-1.43)$ & $-0.27(-1.90)$ & $0.14(1.04)$ & $0.55(4.63)$ & $0.63(5.45)$ \\
ALPHA $_{t+1 \sim t+3}$ & $-0.01(-0.08)$ & $-0.19(-1.20)$ & $-0.25(-1.47)$ & $0.11(0.67)$ & $0.54(3.61)$ & $0.56(3.77)$ \\
ALPHA $_{t+1 \sim t+4}$ & $0.06(0.33)$ & $-0.19(-1.01)$ & $-0.23(-1.13)$ & $0.13(0.64)$ & $0.59(3.29)$ & $0.54(3.06)$ \\
ALPHA $_{t+1 \sim t+5}$ & $0.22(1.06)$ & $-0.18(-0.84)$ & $-0.20(-0.87)$ & $0.15(0.68)$ & $0.51(2.53)$ & $0.30(1.52)$ \\
\hline
\end{tabular}


<표 5>는 각 포트폴리오에 대해 위험을 조정한 후의 초과수익률을 보여주고 있다. 종속변수로 앞의 <표 $4>$ 에서 구성한 포트폴리오의 수익률을 사용하였다. 패널 $\mathrm{A}$ 의 $\mathrm{CAPM}$ 을 사용하여 위험을 조정한 초과수익률 $\mathrm{ALPHA}_{\mathrm{t}+1}$ 의 값을 보면, 5 개의 포트폴리오의 수익률 모두 약간 증가하였다. 결과적으로 순매수금액이 가장 높은 포트폴리오를 매입하고 가장 낮은 포트폴리오를 공매도하는 헤지포트폴리오(High-Low)의 수익률은 $0.61 \%(\mathrm{t}-$ 값 $=7.78)$ 이며 위험을 조정하지 않았을 경우와 동일하다. 패널 B의 Fama and French(1993)의 3요인 모형을 사용하여 위험을 조정하였을 때, 초과수익률이 원래의 수익률보다 약간 감소하는 경향을 볼 수 있으며, $\mathrm{ALPHA}_{t+1}$ 의 헤지포트폴리오(High-Low)의 수익률은 $0.57 \%(\mathrm{t}-$ 값=7.13)로 약간 감소하지만 여전히 통계적 으로 유의미하다. 패널 C의 Fama and French(2015)의 5요인 모형을 사용하여 위험을 조정하면, 5 개 포트폴리오의 초과수익률은 약간 감소하지만 헤지포트폴리오(High-Low)의 수익률은 $0.57 \%$ 로 동일하며 통계적으로 유의미하다. 위의 결과들은 위험을 조정한 후에도 여전히 조세피난처 외국인들의 거래가 코스닥 시장에서 유의한 주가예측력을 가지고 있음을 의미한다.

〈표 6〉조세피난처 외국인의 순매수금액비율과 수익률: 회귀분석 결과

조세피난처로 케이만제도, 버뮤다, 바하마, 미국령 버진아일랜드, 영국령 버진아일랜드 5 개국을 정의하였다. 표본기간은 2006년 1 월부터 2009년 8월(3년 8개월)이다. 거래일 $\mathrm{t}+1$ 일의 수익률을 $\mathrm{t}$ 일의 조세피난처 외국인 순매수금액비율에 대해 회귀분석하였다. ' $\mathrm{NT}(\mathrm{t})$ '는 주식의 거래일 $\mathrm{t}$ 일의 조세피난처 순매수금액 비율이다. ' $\mathrm{NT}+(\mathrm{t})$ '는 주식의 거래일 $\mathrm{t}$ 일의 조세피난처 외국인 순매수금액비율이 0 보다 크면 그 값을 갖고, 작으면 0 의 값을 갖는 변수이며, 반대로 ' $\mathrm{NT}-(\mathrm{t})$ '는 주식의 거래일 $\mathrm{t}$ 일의 조세피난처 순매수금액비율이 0 보다 작으면 그 값을 갖고, 크면 0 의 값을 갖는 변수이다. $\mathrm{D}$ (short)는 주식의 시가총액 대비 공매도금액의 비율이 상위 $50 \%$ 인 경우 1, 하위 $50 \%$ 이면 0 인 더미변수이다. 통제변수인 'Return(t)'는 주식의 거래일 $\mathrm{t}$ 일의 수익률을, 'Size'는 주식의 전년 시점의 기업규모를, ' $\mathrm{BM}$ '은 전년 시점의 장부가대시장가를 나타낸다. 괄호 안은 $\mathrm{t}$-값을 제시한다.

\begin{tabular}{lcccccccc}
\hline & $\mathrm{NT}(\mathrm{t})$ & $\mathrm{NT}+(\mathrm{t})$ & $\mathrm{NT}-(\mathrm{t})$ & $\begin{array}{c}\mathrm{NT}-(\mathrm{t}) \\
\times \mathrm{D} \text { (short) }\end{array}$ & $\mathrm{D}$ (short) & Return(t) & Size & BM \\
\hline$(1)$ & 0.010 & & & & & & & \\
& $(6.87)$ & & & & & & & \\
$(2)$ & 0.005 & & & & & 0.059 & 0.136 & -0.004 \\
& $(3.48)$ & & & & & $(10.64)$ & $(6.37)$ & $(-0.15)$ \\
$(3)$ & & 0.018 & 0.004 & & & & & \\
& & $(6.93)$ & $(1.70)$ & & & & & \\
$(4)$ & & 0.015 & -0.003 & & & 0.059 & 0.151 & -0.007 \\
& & $(5.96)$ & $(-1.46)$ & & & $(10.72)$ & $(6.98)$ & $(-0.24)$ \\
$(5)$ & & 0.018 & -0.001 & 0.009 & 0.232 & & & \\
& & $(7.10)$ & $(-0.32)$ & $(1.97)$ & $(3.84)$ & & & \\
$(6)$ & & 0.017 & -0.005 & 0.009 & -0.123 & 0.028 & 0.214 & 0.002 \\
& $(6.45)$ & $(-1.66)$ & $(2.03)$ & $(-1.67)$ & $(4.82)$ & $(7.93)$ & $(0.07)$ \\
\hline
\end{tabular}

\section{3 개별기업 분석 결과}

이 부분에서는 개별주식들을 사용한 회귀분석 결과들을 설명한다. <표 8>은 식 (1)의 회귀 분석의 결과를 보여주고 있다. 모형 $(1)$ 에서 $\mathrm{NT}(\mathrm{t})$ 의 회귀계수는 $0.010(\mathrm{t}-$ 값 $=6.87)$ 로 유의적이며 
한국증권학회지 제49권 1호 (2020)

조세피난처 순매수금액비율이 주가예측력이 있음을 지지하고 있다. 조세피난처 순매수금액 비율이 $1 \%$ 증가할 때 주식수익률은 $0.010 \%$ 증가한다. Yang(2015b)에서는 조세피난처 순매수 금액비율의 회귀계수 값이 0.006 이었다. 이 역시 코스닥 시장에서의 주가예측력이 유가증권 시장보다 강함을 의미하며 앞에서 확인한 포트폴리오 접근법과도 일치하는 결과이다.

모형 (2)에서는 주식수익률, 기업규모, 장부가대시장가 등의 통제변수를 추가하였다. NT(t)의 회귀계수가 $0.005(\mathrm{t}-$ 값 $=3.48)$ 로 그 크기가 감소하였지만 유의하다. 결과적으로 포트폴리오 접근법과 회귀분석 모두에서 동일하게 조세피난처 순매수금액비율의 주가예측력을 지지하고 있다.

모형 (3)과 (4)에서는 주가예측력의 비대칭성을 고려하기 위해 순매수금액비율이 0보다 클 경우와 작을 경우를 구분하여 각각 $\mathrm{NT}+(\mathrm{t})$ 와 $\mathrm{NT}-(\mathrm{t})$ 변수를 사용하였다. $\mathrm{NT}+(\mathrm{t})$ 는 각 주식의 t일의 조세피난처 외국인 순매수금액비율이 양이면 본래의 변수이며, 아니면 0 의 값을 갖는 변수이다. 반대로 NT-(t)는 $\mathrm{t}$ 일의 조세피난처 외국인 순매수금액비율이 음(-)이면 본래의 변수이며, 아니면 0 의 값을 갖는 변수이다. 우리의 예측과 동일하게 조세피난처 외국인들의 거래가 주식수익률에 유의미한 관계가 있다면, $\mathrm{NT}+(\mathrm{t})$ 와 NT-(t)의 회귀계수는 모두 유의미한 양 $(+)$ 의 값을 가져야 한다. $\mathrm{NT}+(\mathrm{t})$ 가 양 $(+)$ 의 회귀계수를 갖는 것은 조세피난처 외국인들의 매수가 증가할수록 수익률도 증가함을 의미한다. 반면 NT-(t)가 양 $(+)$ 의 회귀계수를 갖는 것은 조세피난처 순매도거래가 증가할수록(순매수거래 값이 작아질수록) 주식수익률은 하락함을 의미한다.

모형 (3)에서 $\mathrm{NT}+(\mathrm{t})$ 의 회귀계수는 0.018 이며, NT-(t)의 회귀계수는 0.004 로 둘 다 양 $(+)$ 의 값을 가진다. 통제변수들을 추가한 모형 (4)에서는 $\mathrm{NT}+(\mathrm{t})$ 의 회귀계수는 0.015 로 여전히 유의하지만 NT- $(\mathrm{t})$ 의 회귀계수는 -0.003 으로 음수로 변한다. 결과적으로 이는 순매수금액비율이 큰 부분에서는 순매수가 클수록 주가가 상승하지만, 순매수금액비율이 작은 부분(순매도금액 비율이 클 부분)에서는 관계가 명확하지 않음을 의미한다. 이는 포트폴리오 접근법 결과를 보면 이해되는 내용이다. <표 $4>$ 와 <표 $5>$ 의 포트폴리오 수익률의 추이를 보면, 순매수금액이 가장 낮은 포트폴리오(Low)의 수익률 $-0.18 \%$ 로 Q2, Q3의 $-0.23 \%$ 보다 오히려 높다. 즉, 순매도 방향으로 갈수록 주식수익률이 감소하지 않는 것이다. 하지만, 순매수 방향에서는 Q4와 가장 높은 포트폴리오(High)의 수익률이 각각 $0.20 \%, 0.43 \%$ 로 순매수금액비율이 증가할수록 주식수익률이 커진다.

$\mathrm{NT}-(\mathrm{t})$ 의 회귀계수 결과가 통계적 유의성이 약한 이유는 앞의 포트폴리오 분석에서 언급한 것과 같이 공매도에 대한 제약을 생각할 수 있다. 이를 실제로 검증하기 위해 간단한 공매도 변수를 추가한 분석을 시행하였다. $\mathrm{D}$ (short)은 각 주식의 시가총액 대비 공매도금액의 비율이 상위 $50 \%$ 인 경우 1 , 하위 $50 \%$ 이면 0 인 더미변수이다. 회귀분석 모형에 NT-(t)와 D(short)의 교차항을 추가하였다. 예측과 같이 공매도가 활발한 종목에서는 순매수금액비율과 수익률의 관계가 유의미하다면, 이는 NT $-(\mathrm{t}) \times \mathrm{D}(\mathrm{short})$ 의 회귀계수는 유의적인 양 $(+)$ 의 값을 가져야 할 것이다. <표 8>의 모형 (5)와 (6)을 보면, $\mathrm{NT}-(\mathrm{t}) \times \mathrm{D}(\mathrm{short})$ 의 회귀계수가 각각 0.009 ( $\mathrm{t}-$ 값 $=1.97)$, $0.009(\mathrm{t}-$ 값 $=2.03)$ 으로 모두 통계적으로 유의미하다. 이는 공매도가 활발한 종목에서는 조세피난처 외국인들의 순매도 증가와 수익률의 하락 관계가 명확하게 발견됨을 의미한다. 
Foreign Trades from Tax Havens on the KOSDAQ

\section{4 추가분석}

다음은 앞에서 확인한 조세피난처 순매수금액비율의 주가예측력이 어떤 특성을 지닌 기업들 에게 집중되는지 보기 위해 두 번 정렬한(double sort) 포트폴리오의 수익률을 살펴보았다. 먼저 기업규모 또는 장부대시장가 비율, 외국인 지분율의 기업특성변수로 기업을 2그룹으로 구분한 후에 그 안에서 조세피난처 순매수금액비율로 구분하여 5 개의 포트폴리오를 구성하였다. $<$ 표 7>은 <표 4>와 동일한 절차에 따라서 $\mathrm{t}$ 일에 구성한 포트폴리오의 $\mathrm{t}+1$ 일의 수익률을 보여주고 있다. 포트폴리오는 매일 재조정되는 방식으로 구성하였다. 또한 해당 기업특성변수로 포트 폴리오를 구성한 후 각 포트폴리오 내에서 조세피난처 외국인 순매수금액비율에 따라 다시 포트폴리오를 설정하였다. 여기서는 순매수금액비율이 가장 낮은 포트폴리오를 공매도하고 가장 높은 포트폴리오를 매수하는 헤지포트폴리오(High-Low)도 구성하였다.

〈표 7〉 기업특성변수와 조세피난처 외국인의 순매수금액비율로 정렬한 포트폴리오의 수익률(\%) 조세피난처로 케이만제도, 버뮤다, 바하마, 미국령 버진아일랜드, 영국령 버진아일랜드 5 개국을 정의하였다. 표본기간은 2006년 1월부터 2009년 8월(3년 8개월)이다. 거래일 t일에 주식의 기업특성변수(여기서는 기업규모, 장부대시장가, 외국인 지분율, 호가스프레드율)에 따라 정렬하여 2개의 포트폴리오를 구성한 후에 다시 조세피난처 순매수금액비율로 정렬하여 5 개의 포트폴리오를 구성한다. 이후 다음 거래일 $\mathrm{t}+1$ 일의 수익률을 계산한다. 포트폴리오는 매일 재조정된다. High-Low는 조세피난처 순매수금액비율이 가장 낮은 포트폴리오를 공매도하고 가장 높은 포트폴리오는 매수하는 헤지포트폴리오의 보유수익률이다. 괄호 안은 $\mathrm{t}$-값을 제시한다.

패널 $\mathrm{A}$ : 기업규모와 조세피난처 외국인 순매수금액비율로 정렬한 포트폴리오의 수익률

\begin{tabular}{lrrrrrr}
\hline & Low & Q2 & \multicolumn{1}{c}{ Q3 } & Q4 & High & High-Low \\
\hline Small Size & $-0.29(-2.62)$ & $-0.51(-4.96)$ & $-0.41(-3.32)$ & $0.07(0.66)$ & $0.46(4.21)$ & $0.74(5.91)$ \\
Big Size & $0.00(-0.03)$ & $-0.02(-0.26)$ & $0.20(1.89)$ & $0.18(1.81)$ & $0.34(3.72)$ & $0.34(3.44)$ \\
\hline
\end{tabular}

패널 B: 장부대시장가 비율과 조세피난처 외국인 순매수금액비율로 정렬한 포트폴리오의 수익률

\begin{tabular}{lrrcccc}
\hline & Low & Q2 & Q3 & Q4 & High & High-Low \\
\hline Low BM & $0.03(0.23)$ & $-0.22(-2.01)$ & $-0.01(-0.11)$ & $0.30(2.69)$ & $0.52(4.97)$ & $0.49(3.76)$ \\
High BM & $-0.21(-2.22)$ & $-0.30(-3.12)$ & $-0.29(-2.72)$ & $0.00(0.05)$ & $0.32(3.48)$ & $0.53(4.97)$ \\
\hline
\end{tabular}

패널 C: 외국인 지분율과 조세피난처 외국인 순매수금액비율로 정렬한 포트폴리오의 수익률

\begin{tabular}{crrrrr}
\hline Low & Q2 & \multicolumn{1}{c}{ Q3 } & \multicolumn{1}{c}{ Q4 } & High & High-Low \\
\hline Low Ownership $-0.20(-1.86)$ & $-0.41(-3.73)$ & $-0.41(-3.40)$ & $0.15(1.22)$ & $0.50(4.40)$ & $0.71(5.52)$ \\
High Ownership $-0.07(-0.71)$ & $-0.09(-0.97)$ & $0.06(0.57)$ & $0.15(1.59)$ & $0.33(3.88)$ & $0.40(4.00)$ \\
\hline
\end{tabular}

<표 7>의 패널 $\mathrm{A}$ 는 기업규모와 조세피난처 순매수금액비율로 두 번 정렬한 포트폴리오들의 수익률을 제시한다. 기업규모가 작은 그룹이든 큰 그룹이든 순매수금액비율이 높을수록 포트 폴리오의 수익률도 높아지는 경향을 보인다. 순매수금액비율이 가장 낮은 포트폴리오를 공매도하고 가장 높은 포트폴리오를 매수하는 헤지포트폴리오(High-Low)의 수익률도 모든 기업규모에서 양(+)의 값으로 유의적이다. 이는 조세피난처 외국인 거래의 주가예측력이 특정 기업규모에만 국한된 것이 아니라 모든 기업들에게 광범위하게 나타나고 있음을 보여준다. 
한국증권학회지 제49권 1호 (2020)

주가예측력의 크기 면에서는 작은 기업규모에서의 헤지포트폴리오 수익률 $0.74 \%$ 가 큰 기업 규모의 헤지포트폴리오 수익률 $0.34 \%$ 보다 2 배 이상 크다. 이는 조세피난처 외국인 거래의 주가예측력이 작은 기업규모에서 더 강함을 의미한다.

패널 $\mathrm{B}$ 는 장부대시장가 비율과 조세피난처 순매수금액비율을 사용하여 구분한 포트폴리오 수익률을 보여준다. 여기서도 순매수금액비율이 높은 포트폴리오일수록 높은 수익률을 보여주고 있다. 헤지포트폴리오 수익률이 각각 $0.49 \%, 0.53 \%$ 로 모두 유의적이며, 장부대시장가 비율이 큰 포트폴리오의 수익률이 더 크기는 하지만 압도적이지 않다.

패널 $\mathrm{C}$ 의 외국인 지분율을 사용하여 2 그룹으로 구분한 포트폴리오 모두에서도 헤지포트폴리오 수익률이 양 $(+)$ 의 값으로 유의적이다. 주목할 점은 외국인 지분율이 작은 헤지포트폴리오의 수익률이 $0.74 \%$ 로 외국인 지분율이 큰 헤지포트폴리오 수익률 $0.40 \%$ 보다 월등히 크다는 것이다. 이는 조세피난처 외국인 거래의 주가예측력이 외국인 지분율이 더 낮은 주식에서 더 집중되어 나타남을 보여준다. 이는 일반적인 상식과 반대되는 결과로서 조세피난처 외국인 거래가 지닌 주가예측력이 외국인들의 실제 주식 보유수준과는 관련성이 적음을 의미한다.

위의 결과들을 통해 여러 기업특성 하에도 조세피난처 외국인 거래가 주가예측력이 있음을 확인할 수 있었다. 구체적으로 언급하면 기업규모가 작고, 외국인 지분율이 낮은 주식에서 주가예측력이 명확히 높게 나타났다.

다음은 앞에서 확인한 주가예측력의 대칭성을 살펴보고자 한다. 조세피난처 순매수금액비율이 음(-)과 양 $(+)$ 의 값을 가지는 기업으로 구분한 후 각각에서 포트폴리오 수익률을 계산하였다. 각 그룹 안에서 순매수금액비율에 따라 두 개의 포트폴리오로 구성한 후 포트폴리오의 $t+1$ 일의 수익률을 계산하였다. 순매수금액비율이 가장 낮은 포트폴리오를 공매도하고 가장 높은 포트 폴리오를 매수하는 헤지포트폴리오(High-Low)의 수익률도 산출하였다.

〈표 8〉 조세피난처 외국인의 순매수금액비율로 정렬한 포트폴리오의 보유수익률(\%): 순매수금액비율을 음 $(-) /$ 양 $(+)$ 으로 구분한 결과

조세피난처로 케이만제도, 버뮤다, 바하마, 미국령 버진아일랜드, 영국령 버진아일랜드 5 개국을 정의하였다. 표본기간은 2006년 1월부터 2009년 8월(3년 8개월)이다. 거래일 t일 주식의 조세피난처 외국인 순매수 금액비율을 음 $(-)$ 과 양 $(+)$ 으로 구분한 후, 각 그룹 안에서 순위에 따라 정렬하여 2 개의 포트폴리오(Low, High)를 구성한다. 다음 거래일 $\mathrm{t}+1$ 일의 수익률을 계산한다. 포트폴리오는 매일 재조정된다. 그리고 다음 거래일부터 2 일 동안의 보유수익률 $(\mathrm{t}+1 \sim \mathrm{t}+2)$ 에서 시작하여 5 일까지의 보유수익률 $(\mathrm{t}+1 \sim \mathrm{t}+5)$ 을 각각 계산하였다. High-Low는 조세피난처 순매수금액비율이 가장 낮은 포트폴리오를 공매도하고 가장 높은 포트폴리오는 매수하는 헤지포트폴리오의 보유수익률이다. 괄호 안은 t-값을 제시한다.

\begin{tabular}{lccccccc}
\hline & \multicolumn{2}{c}{ 순매수금액이 음 $(-)$ 인 경우 } & & \multicolumn{2}{c}{ 순매수금액이 양 $(+)$ 인 경우 } \\
\cline { 2 - 3 } & Low & High & High-Low & Low & High & High-Low \\
\hline $\mathrm{HPR}_{\mathrm{t}+1}$ & $-0.20(-2.68)$ & $-0.32(-3.61)$ & $-0.11(-1.60)$ & & $0.31(3.43)$ & $0.42(5.40)$ & $0.10(1.15)$ \\
$\mathrm{HPR}_{\mathrm{t}+1 \sim \mathrm{t}+2}$ & $-0.20(-1.79)$ & $-0.39(-3.04)$ & $-0.18(-1.82)$ & & $0.37(2.80)$ & $0.53(4.71)$ & $0.15(1.26)$ \\
$\mathrm{HPR}_{\mathrm{t}+1 \sim \mathrm{t}+3}$ & $-0.16(-1.13)$ & $-0.46(-2.85)$ & $-0.30(-2.40)$ & & $0.35(2.09)$ & $0.55(3.82)$ & $0.17(1.23)$ \\
$\mathrm{HPR}_{\mathrm{t}+1 \sim \mathrm{t}+4}$ & $-0.09(-0.57)$ & $-0.50(-2.66)$ & $-0.41(-2.77)$ & & $0.42(2.17)$ & $0.58(3.40)$ & $0.11(0.71)$ \\
$\mathrm{HPR}_{\mathrm{t}+1 \sim \mathrm{t}+5}$ & $0.00(0.00)$ & $-0.54(-2.52)$ & $-0.53(-3.31)$ & & $0.34(1.58)$ & $0.49(2.51)$ & $0.08(0.45)$ \\
\hline
\end{tabular}


Foreign Trades from Tax Havens on the KOSDAQ

<표 8>의 결과를 보면, 순매수금액비율이 양( $(+)$ 인 경우에만 조세피난처의 순매수금액비율이 클수록 더 큰 수익률을 보여주며, 음(-)일 경우에는 반대의 결과를 보여주고 있다. 하지만 순매수금액비율이 양(+)인 경우의 수익률도 그 수치가 작고 통계적으로 유의미하지 않다. 보유기간이 증가하여도 비슷하다. 전반적으로는 순매수금액비율이 음 $(-)$ 인지 아니면 양 $(+)$ 인지의 차이가 주가예측력에 있어서 중요한 요소이고, 그 안에서의 차이는 그 중요성이 작다고 판단된다.

\section{5 강건성 검증(Robustness Check)}

여기서는 지금까지 결과들에 대해 몇 가지 강건성 검증을 실시하였다. 첫째, 하위 표본기간을 통해 포트폴리오 수익률을 재검토하였다. 표본기간 중에는 코스닥 시장의 상승기와 하락기가 혼재되어 있을 뿐 아니라 2008 글로벌 금융위기와 같은 기간도 포함되어 있기 때문에 이를 구분하여 살펴볼 필요가 있다. 전체 3 년 8 개월의 표본기간을 4 개의 하위기간으로 구분하였다. <표 9>의 결과를 보면, 4 기간 모두 앞에서 보여준 전체 기간과 결과가 비슷함을 확인할 수 있다. 헤지포트폴리오(High-Low)도 대부분 양의 수익률을 지니며 통계적으로 유의하다.

〈표 9〉조세피난처 외국인의 순매수금액비율에 따른 포트폴리오의 보유수익률(\%): 하위 표본기간으로 구분한 결과

조세피난처로 케이만제도, 버뮤다, 바하마, 미국령 버진아일랜드, 영국령 버진아일랜드 5 개국을 정의하였다. 표본기간 2006년 1월부터 2009년 8월(3년 8개월)의 기간을 약 1 년씩 4 개의 하위기간으로 구분하였다. 거래일 $\mathrm{t}$ 일 주식의 조세피난처 순매수금액비율에 따라 정렬하여 5 개의 포트폴리오를 구성한 후에 다음 거래일 $\mathrm{t}+1$ 일의 수익률을 계산한다. 포트폴리오는 매일 재조정된다. 그리고 다음 거래일부터 2 일 동안의 보유수익률 $(\mathrm{t}+1 \sim \mathrm{t}+2)$ 에서 시작하여 5일까지의 보유수익률 $(\mathrm{t}+1 \sim \mathrm{t}+5)$ 을 각각 계산하였다. High-Low는 조세피난처 순매수금액비율이 가장 낮은 포트폴리오를 공매도하고 가장 높은 포트폴리오는 매수하는 헤지포트폴리오의 보유수익률이다. 괄호 안은 $\mathrm{t}$-값을 제시한다.

패널 A: 2006년 1월 2006년 12월

\begin{tabular}{lcccccc}
\hline & Low & Q2 & Q3 & Q4 & High & High-Low \\
\hline $\mathrm{HPR}_{\mathrm{t}+1}$ & $-0.19(-1.45)$ & $-0.39(-2.78)$ & $-0.37(-2.64)$ & $0.35(2.77)$ & $0.43(3.54)$ & $0.62(5.26)$ \\
$\mathrm{HPR}_{\mathrm{t}+1 \sim \mathrm{t}+2}$ & $-0.24(-1.28)$ & $-0.51(-2.48)$ & $-0.79(-3.79)$ & $0.26(1.37)$ & $0.55(3.37)$ & $0.79(5.06)$ \\
$\mathrm{HPR}_{\mathrm{t}+1 \sim \mathrm{t}+3}$ & $-0.11(-0.53)$ & $-0.65(-2.66)$ & $-0.83(-3.32)$ & $0.05(0.19)$ & $0.57(2.73)$ & $0.68(3.45)$ \\
$\mathrm{HPR}_{\mathrm{t}+1 \sim \mathrm{t}+4}$ & $-0.09(-0.34)$ & $-0.67(-2.34)$ & $-0.96(-3.28)$ & $-0.04-(0.14)$ & $0.65(2.82)$ & $0.74(3.17)$ \\
$\mathrm{HPR}_{\mathrm{t}+1 \sim \mathrm{t}+5}$ & $-0.03(-0.10)$ & $-0.74(-2.37)$ & $-0.99(-2.98)$ & $-0.23-(0.75)$ & $0.42(1.68)$ & $0.44(1.70)$ \\
\hline
\end{tabular}

패널 B: 2007년 1월 2007년 12월

\begin{tabular}{lcrrrrr}
\hline & Low & \multicolumn{1}{c}{ Q2 } & Q3 & Q4 & \multicolumn{1}{c}{ High } & High-Low \\
\hline HPR $_{\mathrm{t}+1}$ & $0.09(0.68)$ & $-0.31(-2.31)$ & $-0.09(-0.63)$ & $0.35(2.46)$ & $0.49(4.27)$ & $0.40(3.19)$ \\
$\mathrm{HPR}_{\mathrm{t}+1 \sim \mathrm{t}+2}$ & $0.45(2.31)$ & $-0.30(-1.67)$ & $-0.04(-0.17)$ & $0.30(1.52)$ & $0.67(4.09)$ & $0.22(1.27)$ \\
$\mathrm{HPR}_{\mathrm{t}+1 \sim \mathrm{t}+3}$ & $0.67(2.92)$ & $-0.13(-0.56)$ & $-0.09(-0.35)$ & $0.46(1.91)$ & $0.68(3.32)$ & $0.01(0.05)$ \\
$\mathrm{HPR}_{\mathrm{t}+1 \sim \mathrm{t}+4}$ & $0.87(3.17)$ & $-0.05(-0.19)$ & $-0.08(-0.26)$ & $0.72(2.54)$ & $0.69(2.81)$ & $-0.18(-0.71)$ \\
$\mathrm{HPR}_{\mathrm{t}+1 \sim \mathrm{t}+5}$ & $1.06(3.28)$ & $0.09(0.30)$ & $0.17(0.47)$ & $0.79(2.53)$ & $0.68(2.51)$ & $-0.37(-1.29)$ \\
\hline
\end{tabular}


한국증권학회지 제49권 1호 (2020)

〈표 9〉 조세피난처 외국인의 순매수금액비율에 따른 포트폴리오의 보유수익률(\%): 하위 표본기간으로 구분한 결과(계속)

패널 C: 2008년 1월 2008년 12월

\begin{tabular}{lccccrr}
\hline & Low & Q2 & Q3 & Q4 & High & High-Low \\
\hline HPR $_{\mathrm{t}+1}$ & $-0.47(-2.54)$ & $-0.23(-1.12)$ & $-0.46(-2.00)$ & $-0.21(-1.01)$ & $0.00(-0.02)$ & $0.46(2.78)$ \\
$\mathrm{HPR}_{\mathrm{t}+1 \sim \mathrm{t}+2}$ & $-0.73(-2.50)$ & $-0.43(-1.41)$ & $-0.60(-1.77)$ & $-0.60(-1.98)$ & $-0.20(-0.73)$ & $0.52(2.12)$ \\
$\mathrm{HPR}_{\mathrm{t}+1 \sim \mathrm{t}+3}$ & $-0.93(-2.46)$ & $-0.61(-1.64)$ & $-0.72(-1.72)$ & $-0.98(-2.44)$ & $-0.44(-1.24)$ & $0.49(1.49)$ \\
$\mathrm{HPR}_{\mathrm{t}+1 \sim \mathrm{t}+4}$ & $-1.15(-2.68)$ & $-0.80(-1.73)$ & $-0.79(-1.58)$ & $-1.30(-2.87)$ & $-0.75(-1.73)$ & $0.40(1.05)$ \\
$\mathrm{HPR}_{\mathrm{t}+1 \sim \mathrm{t}+5}$ & $-1.16(-2.29)$ & $-0.96(-1.87)$ & $-1.09(-1.90)$ & $-1.38(-2.64)$ & $-1.26(-2.54)$ & $-0.10(-0.23)$ \\
\hline
\end{tabular}

패널 D: 2009년 1월 2009년 8월

\begin{tabular}{lrccccc}
\hline & Low & Q2 & Q3 & Q4 & High & High-Low \\
\hline HPR $_{\mathrm{t}+1}$ & $-0.12(-0.57)$ & $0.11(0.51)$ & $0.13(0.57)$ & $0.37(1.65)$ & $0.99(4.78)$ & $1.12(4.85)$ \\
$\mathrm{HPR}_{\mathrm{t}+1 \sim \mathrm{t}+2}$ & $-0.05(-0.18)$ & $0.70(2.26)$ & $0.41(1.34)$ & $0.66(2.03)$ & $1.57(5.12)$ & $1.63(4.88)$ \\
$\mathrm{HPR}_{\mathrm{t}+1 \sim \mathrm{t}+3}$ & $0.06(0.18)$ & $0.98(2.47)$ & $0.74(1.96)$ & $0.93(2.14)$ & $1.91(4.94)$ & $1.85(4.32)$ \\
$\mathrm{HPR}_{\mathrm{t}+1 \sim \mathrm{t}+4}$ & $0.37(0.84)$ & $1.20(2.69)$ & $1.07(2.44)$ & $1.23(2.47)$ & $2.62(5.75)$ & $2.26(4.31)$ \\
$\mathrm{HPR}_{\mathrm{t}+1 \sim \mathrm{t}+5}$ & $0.72(1.48)$ & $1.23(2.51)$ & $1.20(2.33)$ & $1.51(2.89)$ & $3.13(6.11)$ & $2.41(4.00)$ \\
\hline
\end{tabular}

구체적으로 살펴보면, 패널 $\mathrm{A}$ (2006년 1월 2006년 12월)와 패널 $\mathrm{D}$ (2009년 1월 2009년 8월)의 헤지포트폴리오의 수익률은 각각 $0.62 \%, 1.12 \%$ 로 전체 기간의 헤지포트폴리오 수익률 $0.61 \%$ 보다 크다. 반면 패널 B(2007년 1월 2007년 12월)와 패널 C(2008년 1월 2008년 12월)는 각각 $0.40 \%, 0.4 \% 6$ 로 전체 기간보다 낮다. 주목할 점은 2008년 글로벌 금융위기 기간의 헤지포트폴리오 수익률도 통계적 유의성이 유지되고 있어 다른 하위기간과 큰 차이가 발견되지 않는다.

하위 기간별로 개별 포트폴리오들의 패턴을 보았을 때 약간 다르다. 패널 $\mathrm{A}, \mathrm{B}$ 에서는 순매수 금액이 낮은 포트폴리오는 음(-)수익률을, 순매수금액이 높은 포트폴리오는 양(+)의 수익률을 갖는다. 하지만 패널 $\mathrm{C}$ 의 경우 수익률이 대부분 음(-)이며, 패널 $\mathrm{D}$ 의 수익률은 대부분 양(+)이다. 이는 전반적인 시장 상황과 연관되어 있는 것 같다. <그림 $1>$ 에서 코스닥 시장의 움직임을 관찰하면, KOSDAQ 지수는 2007년 후반부터 하락하고 있으며, 특히 2008년 9월 리만브라더스 파산보호를 신청 후 크게 하락하였다. $\mathrm{KOSDAQ}$ 지수는 2009년부터 상승하여 회복되기 시작한다. 패널 $\mathrm{C}$ 의 하위 표본기간은 코스닥 시장의 하락장에 해당하기 때문에 음 $(-)$ 의 수익률이 많이 발견된다. 반면 패널 $\mathrm{D}$ 는 회복기에 해당하여 양 $(+)$ 의 수익률이 주로 관찰된 것으로 이해할 수 있다. 하지만, 상승기 또는 하락기에 관계없이 모든 하위 표본기간에서 헤지포트폴리오가 유의적인 양(+)의 값을 가지고 있다. 이는 전체 시장 상황과 무관하게 조세피난처 외국인 거래가 주가예측력을 가짐을 의미한다.

둘째, 조세피난처 외국인의 순매수금액비율 외의 다른 측정치를 사용하여 강건성 검증을 실시하였다. <표 $10>$ 의 패널 $\mathrm{A}$ 에서는 이전의 금액을 사용한 변수가 아니라 거래주식수로 측정한 순매수비율을 사용하였다. 즉, 일별 거래량 대비 조세피난처 외국인들의 순매수량을 
Foreign Trades from Tax Havens on the KOSDAQ

사용하여 포트폴리오를 구성하였다. 결과는 거래금액 변수를 사용하였을 때와 크게 다르지 않다. 헤지포트폴리오(High-Low)의 수익률이 $0.59 \%$ 로 거래금액을 사용하였을 때와 비슷하다.

패널 $\mathrm{B}$ 는 조세피난처 순매수금액을 거래금액이 아니라 시가총액으로 나눈 값을 사용하였다. 일별 거래금액은 변동성이 클 수 있기 때문에 이보다 변동성이 적은 시가총액을 사용함으로써 변수의 안정성을 얻을 수 있다. 헤지포트폴리오(High-Low)의 수익률이 $1.00 \%$ 로 원래의 변수를 사용하였을 때보다 수익률이 $40 \%$ 정도 증가한다. 이전보다 더 강한 조세피난처 외국인 순매수의 주가예측력을 보여준다.

〈표 10〉 강건성 분석: 다른 측정치들을 사용하여 정렬한 포트폴리오의 보유수익률 조세피난처로 케이만제도, 버뮤다, 바하마, 미국령 버진아일랜드, 영국령 버진아일랜드 5 개국을 정의하였다. 표본기간은 2006년 1월부터 2009년 8월(3년 8개월)이다. 거래일 $t$ 일 주식의 조세피난처 순매수거래 측정치의 순위로 정렬하여 5 개의 포트폴리오를 구성한 후에 다음 거래일 $\mathrm{t}+1$ 일의 수익률을 계산한다. 포트폴리오는 매일 재조정된다. 그리고 다음 거래일부터 2 일 동안의 보유수익률 $(\mathrm{t}+1 \sim \mathrm{t}+2)$ 에서 시작하여 5 일까지의 보유수익률 $(\mathrm{t}+1 \sim \mathrm{t}+5)$ 을 각각 계산하였다. High-Low는 조세피난처 순매수금액비율이 가장 낮은 포트 폴리오를 공매도하고 가장 높은 포트폴리오는 매수하는 헤지포트폴리오의 보유수익률이다. 패널 $\mathrm{A}$ 는 조세피난처 순매수거래 측정치로 거래주식수를 개념을 사용하여 조세피난처 순매수량을 일별 거래량 으로 나눈 비율을, 패널 $\mathrm{B}$ 는 조세피난처 순매수금액을 시가총액으로 나눈 비율을 사용하였다. 패널 $\mathrm{C}$ 는 조세피난처 순매수금액비율의 변화량을 사용하였다. 괄호 안은 $\mathrm{t}$-값을 제시한다.

패널 $\mathrm{A}$ : 조세피난처 외국인의 순매수량을 일별 거래량(주식수)로 나눈 비율로 정렬한 결과

\begin{tabular}{lcccccc}
\hline & Low & Q2 & Q3 & Q4 & High & High-Low \\
\hline $\mathrm{HPR}_{\mathrm{t}+1}$ & $-0.16(-2.05)$ & $-0.24(-2.77)$ & $-0.23(-2.43)$ & $0.21(2.36)$ & $0.43(5.34)$ & $0.59(7.51)$ \\
$\mathrm{HPR}_{\mathrm{t}+1 \sim \mathrm{t}+2}$ & $-0.14(-1.18)$ & $-0.20(-1.62)$ & $-0.33(-2.39)$ & $0.14(1.06)$ & $0.55(4.80)$ & $0.69(6.17)$ \\
$\mathrm{HPR}_{\mathrm{t}+1 \sim \mathrm{t}+3}$ & $-0.08(-0.54)$ & $-0.20(-1.27)$ & $-0.32(-1.93)$ & $0.08(0.47)$ & $0.56(3.82)$ & $0.64(4.41)$ \\
$\mathrm{HPR}_{\mathrm{t}+1 \sim \mathrm{t}+4}$ & $-0.02(-0.09)$ & $-0.19(-1.02)$ & $-0.32(-1.60)$ & $0.08(0.44)$ & $0.63(3.60)$ & $0.64(3.73)$ \\
$\mathrm{HPR}_{\mathrm{t}+1 \sim \mathrm{t}+5}$ & $0.11(0.56)$ & $-0.20(-0.98)$ & $-0.32(-1.39)$ & $0.09(0.41)$ & $0.51(2.59)$ & $0.40(2.06)$ \\
\hline
\end{tabular}

패널 $\mathrm{B}$ : 조세피난처 외국인 순매수금액을 시가총액으로 나눈 비율로 정렬한 결과

\begin{tabular}{lrrrrrr}
\hline & Low & \multicolumn{1}{c}{ Q2 } & \multicolumn{1}{c}{ Q3 } & \multicolumn{1}{c}{ Q4 } & High & High-Low \\
\hline $\mathrm{HPR}_{\mathrm{t}+1}$ & $-0.53(-5.23)$ & $-0.16(-1.88)$ & $-0.03(-0.36)$ & $0.18(2.34)$ & $0.48(5.25)$ & $1.00(10.39)$ \\
$\mathrm{HPR}_{\mathrm{t}+1 \sim \mathrm{t}+2}$ & $-0.68(-4.65)$ & $-0.16(-1.26)$ & $0.06(0.50)$ & $0.25(2.26)$ & $0.45(3.42)$ & $1.13(8.19)$ \\
$\mathrm{HPR}_{\mathrm{t}+1 \sim \mathrm{t}+3}$ & $-0.82(-4.60)$ & $0.01(0.10)$ & $0.02(0.15)$ & $0.33(2.28)$ & $0.34(2.07)$ & $1.17(6.73)$ \\
$\mathrm{HPR}_{\mathrm{t}+1 \sim \mathrm{t}+4}$ & $-0.91(-4.39)$ & $0.04(0.21)$ & $0.15(0.83)$ & $0.43(2.49)$ & $0.32(1.67)$ & $1.24(6.21)$ \\
$\mathrm{HPR}_{\mathrm{t}+1 \sim \mathrm{t}+5}$ & $-1.02(-4.34)$ & $0.15(0.72)$ & $0.27(1.33)$ & $0.44(2.32)$ & $0.18(0.80)$ & $1.20(5.36)$ \\
\hline
\end{tabular}

패널 C: 조세피난처 외국인 순매수금액비율의 변화량으로 정렬한 결과

\begin{tabular}{lcccccc}
\hline & Low & Q2 & Q3 & \multicolumn{1}{c}{ Q4 } & High & High-Low \\
\hline $\mathrm{HPR}_{\mathrm{t}+1}$ & $-0.10(-1.20)$ & $-0.12(-1.40)$ & $-0.03(-0.29)$ & $0.04(0.52)$ & $0.17(2.05)$ & $0.28(3.28)$ \\
$\mathrm{HPR}_{\mathrm{t}+1 \sim \mathrm{t}+2}$ & $-0.11(-0.90)$ & $-0.10(-0.85)$ & $-0.07(-0.50)$ & $0.04(0.33)$ & $0.27(2.21)$ & $0.38(3.24)$ \\
$\mathrm{HPR}_{\mathrm{t}+1 \sim \mathrm{t}+3}$ & $-0.13(-0.89)$ & $-0.12(-0.76)$ & $-0.07(-0.42)$ & $0.05(0.34)$ & $0.33(2.14)$ & $0.46(3.13)$ \\
$\mathrm{HPR}_{\mathrm{t}+1 \sim \mathrm{t}+4}$ & $-0.06(-0.34)$ & $-0.07(-0.40)$ & $-0.03(-0.18)$ & $-0.01(-0.05)$ & $0.40(2.21)$ & $0.46(2.73)$ \\
$\mathrm{HPR}_{\mathrm{t}+1 \sim \mathrm{t}+5}$ & $0.00(0.02)$ & $-0.05(-0.24)$ & $0.01(0.06)$ & $-0.01(-0.04)$ & $0.33(1.59)$ & $0.33(1.68)$ \\
\hline
\end{tabular}


한국증권학회지 제49권 1호 (2020)

패널 C는 조세피난처 외국인의 순매수금액비율 변화량을 사용하였다. 순매수금액비율의 값 자체도 의미가 있지만 변화량도 주가예측력이 있을 수 있기 때문이다.8) 분석 결과, 헤지포트폴리오 (High-Low)의 수익률이 $0.28 \%$ 로 순매수금액비율 값 자체를 사용하였을 때보다 절반 정도 하락하지만, 통계적 유의성은 여전히 유지된다.

세 번째 강건성 검증은 본 논문 코스닥 시장의 결과를 직접 유가증권시장과 비교하였다. 유가증권시장에 대한 $\operatorname{Yang}(2015 \mathrm{~b})$ 의 연구기간은 2005년 8월부터 2009년 8월까지로 본 연구 기간보다 더 길다. 따라서 두 연구가 겹치는 기간인 2006년 1월부터 2009년 8월까지 동일한 표본기간 자료를 사용한 분석을 통해 유가증권과 코스닥 시장의 포트폴리오를 직접 비교하였다. <표 $11>$ 의 패널 $\mathrm{A}$ 는 이에 대한 분석결과를 제시하고 있다. 여기서는 거래 후 $\mathrm{t}+1$ 일의 수익률 결과를 보고하였다. 보유기간을 늘린 수익률의 결과도 크게 다르지는 않았다. 유가증권시장에서 조세피난처 외국인의 헤지포트폴리오 수익률은 0.27\%로 Yang(2015b)의 연구기간 결과 0.28\% 보다 약간 하락하였다. 코스닥 시장의 수익률은 <표 4>에서 보고한 수치와 동일하다. 두 시장 수익률의 표본기간 909 일 동안의 평균과 함께 차이에 대해서도 검증하였다. 조세피난처 순매수금액비율로 정렬한 5 개의 포트폴리오 중에서 $\mathrm{Q} 4$ 를 제외한 4개의 포트폴리오에서 코스닥과 유가증권시장의 수익률 차이가 유의미하였다. 특히 $\mathrm{Q} 1 \sim \mathrm{Q} 2$ 까지 코스닥과 유가증권시장의 포트폴리오는 모두 음(-)의 수익률을 가지지만, 코스닥과 유가증권 수익률의 차이는 통계적으로 유의미하였다. 두 시장 헤지포트폴리오 수익률의 차이는 $0.34 \%(\mathrm{t}-$ 값 $=4.03)$ 로 통계적으로 유의미 하였다. 이는 코스닥 시장에서 조세피난처 외국인 거래의 주가예측력이 유가증권시장에서 보다 유의미하게 큼을 의미하며, 조세피난처를 통해 외국인으로 위장한 한국인들의 강한 정보력을 지지하고 있다.

<표 11>의 패널 $\mathrm{B}$ 에서는 유가증권과 코스닥 시장에서 조세피난처 외국인들이 거래한 종목들을 하나로 통합하여 분석을 진행하였다. 단순히 기업들을 유가증권과 코스닥 시장으로 나누지 않고, 하나의 표본으로 설정한 후 그 안에서 정보비대칭이나 불확실성에 따라서 주가예측력이 달라지는지를 직접 살펴보고자 하였다. 이를 위해 정보비대칭의 측정치로 기업 규모를 사용하여 2 개의 그룹으로 나누고, 불확실성의 측정치로 변동성을 사용하여 기업을 2 그룹의 나누어서 그 안에서 조세피난처 외국인 거래의 예측력을 검증하였다.

표를 보면, 기업규모가 작은 그룹이든 큰 그룹이든 순매수금액비율이 높을수록 포트폴리오의 수익률도 높아지는 경향을 보인다. 주가예측력의 크기 면에서는 작은 기업규모에서의 헤지 포트폴리오 수익률 $0.47 \%$ 가 큰 기업규모의 헤지포트폴리오 수익률 $0.19 \%$ 보다 2 배 이상 크다. 일반적으로 기업의 규모가 작을수록 정보비대칭이 크기 때문에, 정보비대칭이 클수록 조세피난처 거래의 주가예측력이 더 강함을 의미한다.

다음은 주식 변동성과 조세피난처 순매수금액비율을 사용하여 구분한 포트폴리오 수익률을 보여준다. 주식 변동성은 각 기업들의 표본기간 동안 일별 수익률 절대값의 평균을 사용하였다. 헤지포트폴리오 수익률이 각각 $0.25 \%, 0.50 \%$ 로 모두 유의적이며, 주가 변동성이 큰 포트폴리오의

8) 이에 대하여 제안하여 주신 심사자께 감사드린다. 
Foreign Trades from Tax Havens on the KOSDAQ

수익률이 2 배 정도 더 컸다. 주가 변동성을 불확실성으로 해석할 때, 불확실성이 큰 기업들에서 조세피난처 외국인들의 정보력이 더 강함을 의미한다.

〈표 11〉 조세피난처 외국인의 순매수금액비율로 정렬한 포트폴리오의 보유수익률(\%): 유가증권 대 코스닥 시장

조세피난처로 케이만제도, 버뮤다, 바하마, 미국령 버진아일랜드, 영국령 버진아일랜드 5 개국을 정의하였다. 표본기간은 2006년 1월부터 2009년 8월(3년 8개월, 909거래일)이다. 거래일 t일에 주식의 조세피난처 순매수금액비율에 따라 정렬하여 5 개 포트폴리오를 구성한 후, 다음 거래일 $\mathrm{t}+1$ 일의 수익률을 계산한다. 포트폴리오는 매일 재조정된다. High-Low는 조세피난처 순매수금액비율이 가장 낮은 포트폴리오를 공매도하고 가장 높은 포트폴리오는 매수하는 헤지포트폴리오의 보유수익률이다. 패널 A는 표본기간 동안 코스닥 시장에서 조세피난처 외국인 순매수금액비율에 의한 포트폴리오와 유가증권시장에서의 포트폴리오의 수익률 차이를 보여주고 있다. 패널 $\mathrm{B}$ 는 표본기간 동안의 유가증권과 코스닥 시장 전체 기업을 대상으로 조세피난처 외국인 순매수금액비율에 따른 포트폴리오를 구성하였다. 괄호 안은 $\mathrm{t}$-값을 제시한다.

패널 $\mathrm{A}$ : 포트폴리오 보유수익률 $\left(\mathrm{HPR}_{\mathrm{t}+1}\right)$ 비교

\begin{tabular}{lccrrrr}
\hline & Low & Q2 & \multicolumn{1}{c}{ Q3 } & Q4 & High & High-Low \\
\hline 코스닥 시장 & $-0.18(-2.21)$ & $-0.23(-2.70)$ & $-0.23(-2.42)$ & $0.20(2.30)$ & $0.43(5.40)$ & $0.61(7.80)$ \\
유가증권시장 & $-0.03(-0.50)$ & $-0.03(-0.47)$ & $0.07(1.02)$ & $0.20(2.79)$ & $0.24(3.87)$ & $0.27(8.33)$ \\
차이 & $-0.15(-2.43)$ & $-0.20(-3.10)$ & $-0.30(-4.30)$ & $0.00(0.04)$ & $0.19(3.08)$ & $0.34(4.03)$ \\
\hline
\end{tabular}

패널 $\mathrm{B}$ : 유가증권과 코스닥 전체 표본 분석

\begin{tabular}{|c|c|c|c|c|c|c|}
\hline & Low & Q2 & Q3 & $\mathrm{Q} 4$ & High & High-Low \\
\hline \multicolumn{7}{|l|}{ 기업규모 } \\
\hline Small & $-0.14(-2.37)$ & $-0.19(-2.75)$ & $-0.02(-0.28)$ & $0.18(2.37)$ & $0.33(5.08)$ & $0.47(10.66)$ \\
\hline $\begin{array}{l}\text { Big } \\
\text { 변동성 }\end{array}$ & $0.01(0.23)$ & $0.03(0.39)$ & $0.10(1.36)$ & $0.19(2.57)$ & $0.21(3.12)$ & $0.19(5.60)$ \\
\hline Low & $-0.04(-0.79)$ & $-0.06(-1.21)$ & $0.02(0.37)$ & $0.14(2.54)$ & $0.21(4.16)$ & $0.25(7.35)$ \\
\hline High & $-0.14(-1.82)$ & $-0.09(-1.08)$ & $0.04(0.43)$ & $0.25(2.82)$ & $0.36(4.45)$ & $0.50(10.41)$ \\
\hline
\end{tabular}

마지막으로 본 연구 표본기간 중 2006년 1월부터 6월까지 매도자, 매수자 계좌를 사용하여 6 개월 동안 조세피난처 외국인들의 주식계좌를 분석하였다. <표 $12>$ 는 2006년 1 월부터 6 월까지 코스닥 주식을 거래한 조세피난처 외국인 계좌 1,050 개의 요약통계량을 보여주고 있다. 계좌들의 동안 거래종목수의 중간값은 1 종목이며, 3 분위수 $(\mathrm{Q} 3)$ 는 3 종목이다. 이는 절반 이상의 계좌들이 1 종목을 거래했음을 의미한다. 계좌들 일별 거래량(금액)의 중간값은 약 1 만 7 천주( 2 억 원), 최대값은 약 2 백 50 만주(170억 원)이다. 대부분이 소액 계좌이지만 특정 계좌의 거래량이 특이하게 많음을 확인할 수 있다. 또한 거래양(금액)과 순매수량(금액)의 최대값이 일치하는 것을 보면 거래량이 많으면서 매수나 매도 한쪽으로 극단적인 계좌들이 존재함을 발견할 수 있다.

조세피난처 계좌들 중에서 표본기간 동안 1 종목만을 거래한 계좌들에 초점을 맞춰 세부적으로 살펴보았다. 만약 조세피난처 계좌가 특정기업의 내부자 거래에 이용되고 있다면 그 계좌의 거래는 특정기업에 한정될 가능성이 많지만, 헤지펀드와 같은 일반 투자자에 의해 개설되었다면 거래종목수가 다수일 가능성이 높을 것이다(Berkman et al., 2014). 따라서 계좌들 중에서 
한국증권학회지 제49권 1호 (2020)

1 종목만 거래하는 계좌란 결국 그 기업과 밀접하게 연관되어 있을 가능성이 높으며, 이들 계좌의 집중적인 거래일에 주목할 필요가 있다. Cutler et al.(1989), Fair(2002)의 방법을 따라, 1종목을 거래한 조세피난처의 계좌들이 특이한 거래량을 보이는 날을 찾고, 그 이후에 기업의 어떤 뉴스가 공시되었는지를 금융감독원 전자공시시스템에서 찾아서 기술하였다.

\section{〈표 12〉 계좌별 거래활동에 대한 요약통계량}

조세피난처로 5개국(케이만제도, 버뮤다, 바하마, 미국령 버진아일랜드, 영국령 버진아일랜드)을 정의하였다. 표본기간 2006년 1월부터 2006년 6월(6개월)동안 거래한 조세피난처로부터 외국인 거래계좌수은 총 1,050 개이다. 본 표는 이 계좌들의 표본기간 동안의 거래활동에 대한 요약통계량을 보여주고 있다. 거래 종목수는 각 계좌가 표본기간 6개월 동안 거래한 종목의 수이다. 거래일수는 각 계좌가 표본기간 6 개월 중에서 거래가 존재하는 거래일의 수이다. 일별 거래량과 거래금액은 해당 계좌의 표본기간 동안 거래가 존재하는 날의 일별 거래량과 거래금액의 평균값이다. 일별 순매수량과 순매수금액은 각 계좌의 표본기간 동안의 거래가 존재하는 날의 일별 순매수량(매수주식수-매도주식수)과 순매수금액(매수금액-매도금액)의 평균값을 사용하였다.

\begin{tabular}{lrrrrrrr}
\hline & 평균 & 표준편차 & 최소값 & $\mathrm{Q} 1$ & 중간값 & $\mathrm{Q} 3$ & 최대값 \\
\hline 거래종목수 & 3 & 4 & 1 & 1 & 1 & 3 & 36 \\
거래일수 & 5 & 8 & 1 & 1 & 2 & 6 & 93 \\
일별 거래량(주) & 60,649 & 183,462 & 55 & 5,765 & 16,870 & 48,100 & $2,500,000$ \\
일별 거래금액(천원) & 438,978 & 815,033 & 1,089 & 93,241 & 229,439 & 500,914 & $17,188,886$ \\
일별 순매수량(주) & $-14,223$ & 180,117 & $-2,387,674$ & $-14,192$ & -133 & 8,086 & $2,500,000$ \\
일별 순매수금액(천원) & 377 & 876,754 & $-5,491,650$ & $-157,291$ & $-4,196$ & 141,260 & $17,188,886$ \\
\hline
\end{tabular}

1 종목만을 거래하는 조세피난처 계좌가 비정상적인 거래량을 보이는 사건일(event)을 선택하기 위해서 $\operatorname{Yang}(2015 \mathrm{~b})$ 과 같은 절차를 거쳤다. 1종목만을 거래한 계좌들의 일별 거래량과 거래금액을 구한 후 다음 4 개의 변수를 계산하였다. 2 개는 거래량 변수로 1 종목만 거래한 계좌의 일별 거래량을 해당 주식의 일별 거래량 또는 상장주식수로 나누었다. 나머지 2 개는 거래금액 변수로 1 종목만 거래한 계좌의 일별 거래금액을 해당 주식의 일별 거래금액 또는 시가총액으로 나누었다. 그 다음 일별 거래량(금액) 대비 거래량(금액) 비율이 $20 \%$ 이상인 거래일, 그리고, 상장주식수(시가총액) 대비 일별 거래량(금액) 비율이 $0.5 \%$ 이상일 거래일을 사건일로 선정 하였으며, 총 96 개의 사건일이 선택되었다.

금융감독원 전자공시시스템(DART, http://dart.fss.or.kr)을 통하여 위의 사건일에 대하여 10 일 이내에 발표된 기업공시를 조사하였으며, <표 $13>$ 에 공시내용을 기술하였다. 종목명은 특정기업의 이름이 드러나지 않도록 임의의 번호를 부여하여 처리하였다. 총 96 개 사건일의 공시내역을 $\operatorname{Yang}(2015 \mathrm{~b})$ 과 같이 구분하였을 때, 기업의 이익 및 사업 관련 공시가 37 건, 기업 구조 및 지분과 관련된 공시가 30건, 공시내용이 없는 경우가 29건이었다.

지면관계상 96 개 모든 공시를 다 기술하지 않고 대표적인 공시들을 <표 $13>$ 에 보고하였다. 패널 $\mathrm{A}$ 는 사건일 중에서 기업이익이나 사업과 관련된 공시이다. 조세피난처 계좌가 집중 순매수한 사건일 후에는 당기순이익이 증가 관련된 공시가 있고, 집중 순매도한 사건일 후에는 당기순이익이 감소된 공시가 오는 경향이 발견된다. 특히 매출액 또는 손익의 $30 \%$ (대규모 기업은 15\%) 
Foreign Trades from Tax Havens on the KOSDAQ

이상 변경이 공시되기 전 조세피난처 계좌로부터의 뉴스의 방향과 일치된 대규모 거래가 이루어지는 사례가 있다. 또는 계약수주나 특허취득 등 사업 관련된 호재성 뉴스가 발생한 경우도 있었다. 이런 거래들은 전형적으로 내부정보를 이용하는 것 같은 형태이다.

패널 $\mathrm{B}$ 는 기업구조 및 지분과 관련된 공시이다. 회사합병 결정, 계열회사의 변경과 같은 기업의 구조 변화와 연관된 공시들이 존재하며, 주식매수선택권부여취소, 신주인수권 행사가액의 조정, 유무상증자와 같은 지분의 변동과 관련된 공시들이다.

Yang(2015b)의 연구를 보면 본 연구와 동일한 시기의 유가증권 주식을 1종목 거래한 조세피난처 계좌가 3,204 개이며 거래가 집중된 공시일은 27 개이다. 이에 비해 본 연구의 코스닥 주식을 1 종목 거래한 조세피난처 계좌는 1,050 개로 유가증권시장보다 작지만, 거래가 집중된 공시일은 96 개로 유가증권시장보다 훨씬 많다. 이는 조세피난처 외국인의 정보거래 활동이 유가증권보다 코스닥 시장에서 더 활발함을 암시한다.

〈표 13〉 한 종목만을 거래한 계좌들의 거래금액 상위일자와 주변일 공시내용 조세피난처로 5 개국(케이만제도, 버뮤다, 바하마, 미국령 버진아일랜드, 영국령 버진아일랜드)을 정의하였다. 표본기간 2006년 1 월부터 6 월 동안 위의 조세피난처로부터 외국인 계좌를 조사하여 표본기간 동안 한 종목만을 거래하는 계좌를 추출하였다. 이들 계좌의 일별 거래금액의 해당 주식의 일별 거래금액의 $30 \%$ 를 초과하고, 주식의 시가총액의 $0.5 \%$ 를 초과하는 거래일을 선정하였다. 표에는 사건일 $(0,+10)$ 일 내에 금융감독원공시자료(dart.fss.or.kr)에 보고된 공시가 존재하는 거래일의 공시내용을 기술하였다. 주식 종목명은 임의로 부여한 번호로 처리하였다. 순매수금액과 거래금액의 단위는 천원이며, 비율은 계좌 거래금액을 해당일 총 거래금액으로 나눈 값이다.

패널 $\mathrm{A}$ : 이익 및 사업 관련 공시

\begin{tabular}{|c|c|c|c|c|c|c|c|}
\hline 종목 & 일자 & 계좌수 & 거래횟수 & 순매수금액 & 거래금액 & 비율(\%) & 주변일 공시내용 \\
\hline 1 & 20060627 & 1 & 80 & 430,504 & $1,751,422$ & 24.6 & 단일판매· 공급계약체결(자율공시) \\
\hline 1 & 20060628 & 1 & 75 & 550,985 & 2,358,175 & 23.4 & \\
\hline 1 & 20060629 & 1 & 73 & 565,080 & $1,846,282$ & 30.6 & \\
\hline 2 & 20060310 & 1 & 1 & $-535,337$ & $1,994,980$ & 26.8 & $\begin{array}{c}\text { 매출액 또는 손익 } 30 \% \text { (대규모법인은 } 15 \% \text { ) } \\
\text { 이상 변경(당기순이익 감소, }-864.96 \% \text { ) }\end{array}$ \\
\hline 3 & 20060220 & 1 & 20 & $-384,095$ & $1,769,021$ & 21.7 & $\begin{array}{c}\text { 매출액 또는 손익 } 30 \% \text { (대규모법인은 } 15 \% \text { ) } \\
\text { 이상 변경(당기순이익 감소, }-45.7 \%)\end{array}$ \\
\hline 4 & 20060315 & 1 & 42 & $-393,349$ & 791,571 & 49.7 & $\begin{array}{c}\text { 매출액 또는 손익 } 30 \% \text { (대규모법인은 } 15 \% \text { ) } \\
\text { 이상 변경(당기순이익 감소, }-78.0 \%)\end{array}$ \\
\hline 5 & 20060112 & 1 & 60 & 217,978 & 896,610 & 24.3 & $\begin{array}{c}\text { 매출액 또는 손익 } 30 \% \text { (대규모법인은 } 15 \% \text { ) } \\
\text { 이상 변경(당기순이익 증가, } 183.4 \% \text { ) }\end{array}$ \\
\hline 6 & 20060105 & 1 & 67 & $1,004,534$ & $4,090,601$ & 24.6 & 자진공시(공급계약체결) \\
\hline 7 & 20060215 & 1 & 3 & 534,160 & $1,205,571$ & 44.3 & 자진공시(용역수주) \\
\hline 8 & 20060510 & 1 & 152 & $2,799,242$ & $10,040,943$ & 27.9 & 특허취득 \\
\hline 9 & 20060426 & 1 & 288 & $-237,052$ & $1,063,002$ & 22.3 & $\begin{array}{l}\text { 영업(잠정)실적(공정공시) } \\
\text { (당기순이익 감소, - } 29.84 \%)\end{array}$ \\
\hline 10 & 20060426 & 1 & 1 & $2,546,000$ & $4,861,528$ & 52.4 & $\begin{array}{l}\text { 영업(잠정)실적(공정공시) } \\
\text { (당기순이익 감소, - }-48.3 \%)\end{array}$ \\
\hline 11 & 20060216 & 1 & 48 & $-533,162$ & $1,775,447$ & 30.0 & $\begin{array}{l}\text { 영업(잠정)실적(공정공시) } \\
\text { (당기순이익 감소, - } 56.8 \%)\end{array}$ \\
\hline 12 & 20060216 & 2 & 9 & $9,533,538$ & $9,533,538$ & 35.5 & $\begin{array}{l}\text { 영업(잠정)실적(공정공시) } \\
\text { (순이익 전년동기대비 } 2,277 \% \text { 증가) }\end{array}$ \\
\hline
\end{tabular}


한국증권학회지 제49권 1호 (2020)

〈표 13〉 한 종목만을 거래한 계좌들의 거래금액 상위일자와 주변일 공시내용(계속) 패널 $\mathrm{B}:$ 기업 구조 및 지분관련 공시

\begin{tabular}{rccrrrrl}
\hline 종목 & 일자 & \multicolumn{2}{l}{ 계좌수 거래횟수 순매수금액 } & 거래금액 & \multicolumn{1}{l}{ 비율(\%) } & \multicolumn{1}{c}{ 주변일 공시내용 } \\
\hline 13 & 20060215 & 1 & 52 & 694,431 & $2,682,174$ & 25.9 & 예비투자설명서[사채] \\
14 & 20060125 & 1 & 29 & $-10,212,077$ & $24,384,135$ & 41.9 주식매수선택권부여취소 \\
15 & 20060510 & 2 & 2 & 0 & $3,960,828$ & 100.0 계열회사 변경(계열회사 추가) \\
16 & 20060417 & 1 & 54 & $-180,933$ & 895,237 & 20.2 신주인수권행사가액의조정 \\
17 & 20060503 & 1 & 171 & $-7,369,324$ & $16,706,684$ & 44.1 & 유무상증자 결정 \\
18 & 20060206 & 1 & 1 & $-4,059,046$ & $11,027,555$ & 36.8 & 전환청구권행사 \\
18 & 20060210 & 1 & 1 & $-4,321,690$ & $12,166,517$ & 35.5 & \\
19 & 20060113 & 1 & 177 & $-2,953,515$ & $9,579,166$ & 30.8 회사합병결정 \\
19 & 20060120 & 1 & 113 & $4,290,495$ & $13,252,369$ & 32.4 & \\
20 & 20060607 & 1 & 34 & 431,447 & $1,674,364$ & 25.8 & 전환사채발행결정 \\
21 & 20060608 & 1 & 60 & $-223,373$ & 665,570 & 33.6 & 신주인수권행사가액의조정 \\
21 & 20060609 & 1 & 112 & $-492,541$ & $1,128,643$ & 43.6 & \\
21 & 20060614 & 1 & 61 & $-178,070$ & 405,612 & 43.9 & \\
22 & 20060310 & 1 & 99 & $-1,816,932$ & $5,429,843$ & 33.5 & 주식매수선택권부여취소 \\
23 & 20060203 & 1 & 36 & 310,506 & $1,163,676$ & 26.7 & 임원 · 주요주주특정증권등소유상황보고서 \\
& & & & & & & (외국법인 주식취득) \\
\hline
\end{tabular}

\section{6 해석 및 토론}

지금까지 다양한 실증분석을 통해 코스닥 시장에서 조세피난처 외국인 순매수가 강한 주가 예측력을 지님을 확인할 수 있었다. 조세피난처 순매수가 낮은 주식을 공매도한 후 높은 주식을 매수하는 전략이 일평균 $0.61 \%$ (월 13.42\%)의 수익률을 유의미하게 제공하고 있다. 이러한 초과수익률의 크기가 어느 정도인지 판단하기 위해 다른 문헌들을 참고할 필요가 있다. 유가증권시장을 대상으로 조세피난처 거래에 대해 동일한 분석을 시행한 Yang(2015b)은 헤지포트폴리오 수익률로 일 평균 $0.28 \%$ (월 6.2\%)를 보고하고 있다. 코스닥 시장에서의 헤지 포트폴리오 수익률은 유가증권시장에서의 2 배 정도에 해당한다. 이는 코스닥 시장에 들어오는 조세피난처 외국인들이 거래의 주가예측력이 유가증권시장보다 더 강함을 의미한다.

Diether et al.(2008)은 본 연구 비슷하게 미국의 공매도 거래자료를 사용하여 일별 포트폴리오 구성하였을 때, 공매도 거래비율이 높은 주식을 공매도하고 공매도 거래비율이 낮은 주식을 매수하는 거래전략이 NYSE에서는 일평균 $0.063 \%$, Nasdaq에서는 $0.064 \%$ 의 수익률은 줌을 보고하고 있다. 이런 미국의 결과들을 보았을 때도 한국 코스닥 시장의 결과는 놀라운 수치이다.

한국 시장을 대상으로 한 연구로는 Ko and $\operatorname{Kim}(2004)$ 가 있다. 이들은 내국인 개인투자자 보유비중 상위 30 개 주식을 공매도하고 외국인 보유 비중 상위 30 개 주식의 포트폴리오를 매수하는 월별 포트폴리오를 구성한 결과, 월평균 $1.65 \%$ 의 수익률을 얻었다. Fama-French 3 요인을 사용한 위험조정 수익률은 $2.52 \%$ 에 달하였다. 하지만, 본 연구 헤지포트폴리오의 월 수익률 $13.42 \%$ 는 이런 월별수익률을 초과하는 상당한 크기이다. 이는 조세피난처로부터의 외국인들이 유의미한 사적정보를 가지고 있음을 뒷받침하는 증거들이라 생각된다. 
Foreign Trades from Tax Havens on the KOSDAQ

조세피난처 외국인 거래의 주가예측력의 원천에 대해 Yang(2015b)은 2가지의 가능성을 제시하고 있다. 첫째, 조세피난처 외국인들이 '위장한 한국인'으로서 한국 기업의 내부자일 수 있다. 즉, 한국인이 조세피난처를 이용하여 페이퍼컴퍼니를 설립한 후 외국인으로 위장하여 한국 주식을 거래하는 것이다. 이런 실례는 어렵지 않게 찾아볼 수 있다. 2013년 초 뉴스타파 등 미디어의 보도를 통해서나 CJ 비자금 사건을 통해 실제로 많은 한국인들이 조세피난처를 이용하고 있음이 사실로 확인되었다. 이후 금융감독원은 상황의 심각성을 인식하고 이들의 불법 증권거래를 감시하기 위한 대책까지 마련하여 발표하였다.

두 번째 가능성은 진짜 외국인들이다. 특히 금융이 발달한 선진국의 금융기관들은 조세피난처가 제공하는 여러 이점들을 누리기 위해 조세피난처를 경유하여 한국에 투자할 수 있다. 조세피난처는 비밀주의를 원칙으로 하며 익명성을 보장해 주기 때문에 많은 헤지펀드들은 조세상의 이점을 위해 또는 규제를 피하기 위해서 조세피난처를 이용하고 있다(Kim and Wei, 2002). 특히 많은 헤지펀드들은 조세피난처에 등록되어 있다. 이들은 고급인력으로 운영되기 때문에 일반인에 비해 우월한 정보력을 가지고 있다.

본 논문에 사용된 자료를 통해서는 조세피난처 외국인이 진짜 외국인 투자자인지 아니면 위장 한국인지 정확히 분별할 수 없다. 하지만 조세피난처 외국인이 위장 한국인일 수 있는 가능성을 배제할 수 없다. Yang(2015b)는 유가증권시장에서도 조세피난처 외국인 거래의 주가예측력의 상당부분이 내국인에 의한 내부자거래에서 기인함을 주장하였다. 코스닥 시장에 유가증권시장에 비해 더 불투명하고 유동성이 작은 시장임을 생각할 때, 불법적인 내부자거래의 가능성은 더 증가할 수 있다. 불투명한 시장은 일반적으로 투자자들의 관심도가 떨어지고 불공정거래가 적발될 가능성도 낮아진다. 또한 유동성이 작은 경우 소규모 거래로도 큰 가격충격을 유발할 수 있기 때문에 더 큰 부당이익을 기대할 수 있다. 이런 이유들로 인해 불공정행위는 기업규모가 작고 유동성이 적은 주식에서 많이 발생하게 된다(Ben-David et al., 2013). 한국에서 코스닥 시장은 이미 유가증권시장에 비해서 내부자 거래, 주가조작 등의 불공정 거래가 훨씬 더 심한 시장으로 알려져 있다. 이러한 사실은 조세피난처 외국인의 강한 주가예측력의 원인 중 하나로 외국인을 위장한 한국인을 통한 내부자 거래의 가능성을 유추할 수 있다.

또한 앞의 <표 $3>$ 에서 조세피난처 외국인들이 거래규모 상위 종목들의 상당수가 이후에 상장폐지된 기업들임을 확인 할 수 있었다. 그 중에서는 불공정거래와 연관된 기업들도 있으며 많은 기업이 소액주주들의 피해로 인해 소송을 경험하기도 하였다. 이런 과정에서 조세피난처가 불법적으로 이용되었을 가능성이 있다. 만일 기업의 경영자들이 조세피난처를 이용하여 일반 주주들에게 손해를 끼친 것이라면 이는 또 다른 사회적인 문제가 될 수 있을 것이다.

그리고 <표 6>에서 조세피난처 외국인 거래의 주가예측력이 기업규모가 작고, 외국인 지분율이 낮은 주식에 더 집중되어 있었다. 그런데, 이는 일반적으로 알려진 외국인들의 주식선택 행동과 일치하지 않는다. 한국 주식시장에서 Khil et al.(2006)은 외국인들이 기업 규모가 크며 유동성이 풍부한 주식을 선호하는 것을 발견하였으며 다른 외국의 경우도 동일한 현상을 보고하고 있다(Kang and Stulz, 1997). 외국인들이 내국인에 비해 정보우위에 있다면 그들이 선호하는 특성의 주식에서 주가예측력이 집중되어야 하겠지만, 본 연구에서는 반대로 외국인들이 적게 
한국증권학회지 제49권 1호 (2020)

보유하며 기업규모가 작은 주식에서 더 높은 주가예측력이 발견된다. 이런 현상은 조세피난처 외국인들이 우리가 알고 있는 일반적인 외국인들과 다른 투자자, 즉 위장 한국인일 가능성이 더 큼을 시사한다.

\section{4. 결론}

본 연구는 코스닥 시장에서 조세피난처의 외국인 거래가 주가예측력을 가지는지를 검증하였다. 실증분석의 방법으로는 재무에서 일반적으로 사용하는 포트폴리오 접근법과 회귀분석을 사용 하였다.

실증분석 결과, 포트폴리오 수익률과 회귀분석 방법 모두 조세피난처 거래가 미래 주가에 대한 예측력을 가짐을 보여주었다. 포트폴리오를 통해 분석에서 조세피난처 외국인의 순매수 금액비율이 높은 포트폴리오일수록 높은 수익률을 가졌다. 순매수금액이 가장 낮은 포트폴리오를 공매도하고 가장 높은 포트폴리오를 매수하는 헤지포트폴리오도 유의적인 양(+)의 수익률을 가졌으며, 그 크기에 있어서 기존 문헌에서 보고한 유가증권시장에서의 헤지포트폴리오 수익률의 2 배에 이르렀다. CAPM을 사용하여 위험을 조정한 후의 수익률도 동일한 결과를 보여주었다. 또한 기업특성별로 구분하였을 때, 기업규모가 작고 외국인 지분율이 낮은 주식들에서 더 높은 예측력을 보였다.

지금까지의 코스닥 시장에서의 분석결과들은 기존의 유가증권시장에 대한 연구와 더불어 한국 주식시장에서 조세피난처 외국인들이 정보거래자임을 강력하게 지지한다. 코스닥 시장에서의 주가예측력이 기존에 보고한 유가증권시장보다 더 강함을 보여주고 있다. 이는 정보거래자들이 더 큰 이익을 얻을 수 있는 정보비대칭이 심한 불투명한 시장을 통하여 거래하고자 하는 유인이 존재함을 의미한다. 또한 한국에서 코스닥 시장은 유가증권시장에 비해서 불공정 거래가 훨씬 더 심각한 시장임을 고려할 때, 조세피난처 외국인의 강한 주가예측력의 주요한 이유 중 하나로 외국인을 위장한 한국인을 통한 내부자 거래의 가능성을 배제할 수 없다. 이는 금융감독 측면에서도 조세피난처 거래를 주시할 필요가 있음을 시사한다.

하지만 본 연구는 한계점도 가지고 있다. 조세피난처 외국인 거래들 중에서 한국인 내부거래자를 정확히 구분해 낼 수 있는 자료가 존재하지 않는다. 이를 살펴보기 위해서는 개별 기업에 대한 사례 연구방법이 더 유효할 것으로 생각된다. 뉴스 등을 통해서 외부에 알려진 사건이나 재판을 통해 드러난 판례 등을 통하여 연구한다면 조세피난처 외국인들의 정체나 전략에 대해 더 구체적으로 확인 할 수 있으리라 생각된다. 이런 다양한 방법들을 통해 조세피난처 외국인들의 거래가 향후에 더 연구되길 기대해 본다. 
Foreign Trades from Tax Havens on the KOSDAQ

\section{References}

Admati, A. R., and P. Pfleiderer, 1989, Divide and Conquer: A Theory of Intraday and day-of-the-week Mean Effects, Review of Financian Studies, Vol. 2, pp. 189-223.

Anand, A., and S. Chakravarty, 2007, Stealth Trading in Options Markets, Journal of Financial and Quantitative Analysis, Vol. 42, pp. 167-187.

Barclay, M. J., and J. B. Warner, 1993, Stealth Trading and Volatility: Which Trades Move Prices?, Journal of financial Economics, Vol. 34, pp.281-305.

Ben-David, I. K, F. Franzoni, A. Landier, and R. Moussawi, 2013, Do Hedge Funds Manipulate Stock Prices?, Journal of Finance, Vol. 68, pp. 2383-2434.

Berkman, H., P. D. Koch, and P. J. Westerholm, 2014, Informed Trading Through the Accounts of Children, Journal of Finance, Vol. 69, pp. 363-404.

Brennan, M. J., and A. Subrahmanyam, 1995, Investment Analysis and Price Formation in Securities Markets, Journal of Financial Economics, Vol. 38, pp. 361-381.

Chakravarty, S., 2001, Stealth-Trading: Which Traders' Trades Move Stock Prices?, Journal of Financial Economics, Vol. 61, pp. 289-307.

Choe, H., B. C. Kho, and R. M. Stulz, 1999, Do Foreign Investors Destabilize Stock Markets? The Korean Experience in 1997, Journal of Financial Economics, Vol. 54, pp. 227-264.

Choe, H., J. M. Jung, and W. B. Lee, 2003, Stealth Trading on the Korea Stock Market, Asian Review of Financial Research, Vol. 16 (2), pp. 1-29.

Cutler, D. M., J. M. Poterba, and L. H. Summers, 1989, What Moves the Stock Market, Journal of Portfolio Management, Vol. 15 (3), pp. 4-11.

Dharmapala, D., and J. R. Hines Jr., 2009, Which Countries Become Tax Havens?, Journal of Public Economics, Vol. 93, pp. 1058-1068.

Diether, K. B., K. H. Lee, and I. M. Werner, 2009, Short-Sale Strategies and Return Predictability, Review of Financial Studies, Vol. 22, pp. 575-607.

Dyreng, S. D., B. P. Lindsey, and J. R. Thornock, 2013, Exploring the Role Delaware Plays as a Domestic Tax Haven, Journal of Financial Economics, Vol. 108, pp. 751-772.

Easley, D., and M. O’Hara, 1987, Price, Trade Size, and Information in Securities Markets, Journal of Financial Economics, Vol. 19, pp. 69-90.

Easley, D., and M. O'Hara, 2004, Information and the Cost of Capital, Journal of Finance, Vol. 59, pp. 1553-1583.

Easley, D., S. Hvidkjaer, and M. O'Hara, 2002, Is Information Risk a Determinant of Asset Returns?, Journal of Finance, Vol. 57, pp. 2185-2221.

Fair, R. C., 2002, Events that Shook the Market, Journal of Business, Vol. 75, pp. 713-731.

Fama, E. F., and K. R. French, 1993, Common Risk Factors in the Returns on Stocks and 
한국증권학회지 제49권 1호 (2020)

Bonds, Journal of Financial Economics, Vol. 33, pp. 3-56.

Fama, E. F., and K. R. French, 2015, A Five-Factor Asset Pricing Model, Journal of Financial Economics, Vol. 116, pp. 1-22.

Glosten, L. R., and P. R. Milgrom, 1985, Bid, ask and Transaction Prices in a Specialist Market with Heterogeneously Informed Traders, Journal of Financial Economics, Vol. 14, pp. $71-100$.

Grammig, J., D. Schiereck, and E. Theissen, 2001, Knowing me, Knowing You: Trader Anonymity and Informed Trading in Parallel Markets, Journal of Financial Markets, Vol. 4, pp. $385-412$.

Grossman, S. J., and J. E. Stiglitz, 1980, On the Impossibility of Informationally Efficient Markets, American Economic Review, Vol. 70, pp. 393-408.

Hanlon, M., E. L. Maydew, and J. R. Thornock, 2015, Taking the Long Way Home: U.S. Tax Evasion and Offshore Investments in U.S. Equity and Debt Markets, Journal of Finance, Vol. 70, pp. 257-287.

Hines Jr, J. R., and E. M. Rice, 1994, Fiscal Paradise: Foreign Tax Havens and American Business, Quarterly Journal of Economics, Vol. 109, pp. 149-182.

Jung, H. S., and S. H. Kim, 2017, The Effects of Stock Holdings and Trading by Tax Haven Investors, Journal of Insurance and Finance, Vol. 28, pp. 97-134.

Kang, J. K., and R. M. Stulz, 1997, Why is there a Home Bias? An Analysis of Foreign Portfolio Equity Ownership in Japan, Journal of Financial Economics, Vol. 46, pp. 3-28.

Khil, J., N. Y. Kim, and Y. S. Sohn, 2006, The Impact of the Investors' Trading Behavior on the Return and the Volatility in the Recent Korean Stock Market, Asia-Pacific Journal of Financial Studies, Vol. 35 (3), pp. 77-106.

Kim, W., and S. J. Wei, 2002, Offshore Investment Funds: Monsters in Emerging Markets?, Journal of Development Economics, Vol. 68, pp. 205-224.

Ko, K., and K. Kim, 2004, Portfolio Performance and Characteristics of Each Investor Type: Individuals, Institutions, and Foreigners, Asia-Pacific Journal of Financial Studies, Vol. 33 (4), pp. 35-62.

Kyle, A. S., 1985, Continuous Auctions and Insider Trading, Econometrica, Vol. 53, pp. 1315-1335.

OECD, 2000, OECD 2000 Progress Report: Towards Global Tax Co-Operation: Progress in Identifying and Eliminating Harmful Tax Practices.

Yang, C. W., 2015a, The Impact of Capital Flows from Tax Havens on the Korean Stock Market, Asian Review of Financial Research, Vol. 28 (2), pp. 195-234.

Yang, C. W., 2015b, The Return Predictability of Foreign Investors' Trading from Tax Havens in the Korean KOSPI Market, Korean Journal of Financial Studies, Vol. 44 (5), pp. 997-1030. 